\author{
Marquette University \\ e-Publications@Marquette
}

$5-2013$

\title{
The Effect of Foreign Direct Investment on International Migration: Does Education Matter?
}

\author{
Miao Wang \\ M. C. Sunny Wong \\ University of San Francisco \\ Jim Granato \\ University of Houston - Main
}

Marquette University, grace.wang@marquette.edu

Follow this and additional works at: https://epublications.marquette.edu/econ_fac

Part of the Economics Commons

\section{Recommended Citation}

Wang, Miao; Wong, M. C. Sunny; and Granato, Jim, "The Effect of Foreign Direct Investment on International Migration: Does Education Matter?" (2013). Economics Faculty Research and Publications. 138.

https://epublications.marquette.edu/econ_fac/138 
Marquette University

e-Publications@Marquette

\section{Economics Faculty Research and Publications/College of Business}

This paper is NOT THE PUBLISHED VERSION; but the author's final, peer-reviewed manuscript. The published version may be accessed by following the link in the citation below.

The World Economy, Vol. 36, No. 5 (2013): 537-562. DOl. This article is (C [Wiley] and permission has been granted for this version to appear in e-Publications@Marquette. [Wiley] does not grant permission for this article to be further copied/distributed or hosted elsewhere without the express permission from [Wiley].

\section{The Effect of Foreign Direct} Investment On International

\section{Migration: Does Education Matter?}

\section{Miao Wang}

Department of Economics, Marquette University, Milwaukee, WI

\section{C. Sunny Wong}

Department of Economics, San Francisco University, San Francisco, CA

Jim Granato

Department of Political Science and Hobby Center for Public Policy, University of Houston, Houston, TX 


\section{Abstract}

Using migration data in 1990 and 2000, we find that inward foreign direct investment (FDI) in non-OECD countries affects the out-migration of individuals with tertiary and secondary education to OECD countries originating the investments, but has no significant effect on the out-migration of individuals with primary education. Distinguishing between linkage and home effects, our results show a dominant home effect of FDI for individuals with tertiary education, but a stronger linkage effect for those with secondary education. The existing stock of former migrants in foreign countries influences the out-migration of individuals with primary education.

Said Anney Unnikrishnan, a personnel manager at 24/7, 'I finished my MBA and I remember writing the GMAT and getting into Purdue University. But I couldn't go because I couldn't afford it. I didn't have the money for it. Now I can, [but] I see a whole lot of American industry has come into Bangalore and I don't really need to go there. I can work for a multinational sitting right here. So I still get my rice and sambar [a traditional Indian dish], which I eat ... I still continue with my Indian food and I still work for a multinational. Why should I go to America?' (Friedman, 2005, p. 28)

\section{Introduction}

The past several decades have seen a dramatic increase in international labour mobility. From 1960 to 2005, the international migrants stock has gone up from 75 million to 191 million, representing an unprecedented 155 per cent increase (United Nations, 2006). The magnitude of growth in the international labour movement has attracted much attention from both policymakers and academic researchers, with much of the research concentrating on the relationship between international trade and migration. Such a focus is understandable given the importance of trade and the fact that standard trade theory considers trade in final goods as a substitute for factors moving across international borders. However, compared to trade, capital flows by many measures have grown even faster. For instance, world foreign direct investment (FDI) inflows rose from \$55 billion in 1980 to $\$ 1,243.7$ billion in 2010, increasing by a remarkable 2,161 per cent (United Nations 2011). ${ }^{1}$

In this paper, we explore the relationship between inward FDI in less developed countries (LDCs) and the migration of individuals with different levels of education from LDCs to developed OECD countries (DCs) originating the investments. Our study adds to the small literature on FDI and migration and contributes to the literature by systematically examining the effect of inward FDI on the out-migration of individuals with three levels of education, namely primary, secondary and tertiary education.

The number of studies on FDI migration is gradually growing in the past decade. However, as pointed out by Javorcik et al. (2011, p. 231), 'the link between FDI and migration remains relatively unexplored'. The existing empirical research on this topic, in general, can be categorised into two branches, investigating the FDImigration dependence from two distinct directions.

The first branch devotes attention to the effect of inward FDI in a host country on the out-migration from this host (see Hayase, 2001; Aroca and Maloney, 2005; Sanderson and Kentor, 2008). Hayase (2001, p. 555), employing data on FDI from Japan to East Asian economies, states that 'such investment could influence international migration positively or negatively ... further empirical studies are needed to clarify these relationships'. Aroca and Maloney (2005) study the internal migration patterns in Mexico. Taking the US as the 33rd state of Mexico, the authors find that a doubling of FDI in Mexico from the US could decrease total 
migration from Mexico to the US by 1.5 to 2 per cent. Sanderson and Kentor (2008), on the other hand, focus on total FDI in 25 LDCs and the net emigration from these LDCs between 1985 and 2000 and argue that inward FDI stock from the rest of the world in LDCs increases the net emigration from these countries over time.

The second set of studies looks at the reverse direction where migration leads to (or affects) capital flows (see Gao, 2003; Tong, 2005; Kugler and Rapoport, 2007; Docquier and Lodigiani, 2010; Javorcik et al., 2011). Gao (2003) finds a positive relationship between the share of Chinese population in source countries of FDI and inward FDI in China from those countries. Kugler and Rapoport (2007), with US Census data, study immigrants in the US by country of origin and the US FDI abroad to the migrants-sending countries. They show that the skilled migration from a country to the US negatively affects FDI outflows from the US to that country. Also using data from the US Census in 1990 and 2000, Javorcik et al. (2011)point out that a 1 per cent rise in migrants stock in the US leads to a 0.35 to 0.42 per cent increase in US FDI in those migrants-sending countries. Employing a broader sample, Docquier and Lodigiani (2010) find that the stock of migrants from LDCs to OECD countries and the stock of FDI in LDCs from OECD countries are positively correlated, based on both crosssectional and panel models.

Empirical research on FDI-migration typically does not distinguish between migrants with different levels of skills and mainly focuses on FDI and aggregate migration. There are only a few exceptions including Kugler and Rapoport (2007), Docquier and Lodigiani (2010) and Javorcik et al. (2011), all of which examine how migration leads to FDI. For example, Kugler and Rapport distinguish between migrants with primary, secondary and tertiary education, and Javorcik et al. study migrants in the US with at least tertiary education in addition to the total number of migrants.

In contrast, our paper investigates, and to the best of our knowledge is among the first ones to do so, how inward FDI affects out-migration by migrants' level of education. Extending prior research on the effect of FDI on migration and complementing Kugler and Rapoport (2007), Docquier and Lodigiani (2010) and Javorcik et al. (2011), our analysis aims to shed some light on the empirical evidence of the heterogeneous effects of FDI on skilled and unskilled migration.

Foreign affiliates of multinational corporations (MNCs) can be substantially different from domestic firms. Most studies on MNCs point out that there is performance gap between foreign affiliates and domestic firms. For example, Howenstine and Zeile (1994) find that the average size of foreign-owned establishments in the US is larger, pay higher wages and is more capital-intensive than the US-owned establishments. Similarly, Barba Navaretti and Venables (2004), using a larger sample, argue that foreign affiliates of the US, Japan, the UK, Germany and France are larger, more capital-intensive and more productive than G5's domestic firms. ${ }^{2}$ Consequently, inward FDI may favour skilled workers over unskilled workers in a host country by shifting the relative demand for skilled and unskilled labour in the host country. Feenstra and Hanson (1996) introduce a North-South model where the South has a comparative advantage in producing unskilled labour-intensive products initially. As the South is open to capital flows from the North, the demand for skilled labour rises in both regions. Feenstra and Hanson (1997) also find that an increase in FDI is positively correlated with the increase in demand for high-skilled labour in Mexico and accounts for approximately 50 per cent of the increase in the wage for skilled labour in some regions of Mexico. Figini and Görg (1999) examine FDI in the manufacturing sector in Ireland and argue that MNCs introduce a higher level of technology in the host country. The authors point out that there is a U-shaped relationship between wage inequality and the presence of multinationals in Ireland. Similar results are echoed in Driffield and Taylor (2002). Using panel data on FDI in the 
UK, Driffield and Taylor find that FDI in the UK has a positive effect on the relative demand of high-skilled labour, hence a positive effect on the employment of high-skilled labour relative to low-skilled labour in manufacturing industries.

Since prospective migrants from a country are not homogeneous in terms of their skills or education levels, we should expect FDI to have different effects on the out-migration of individuals with different skills. Using data on international migration from 19 LDCs to 14 DCs in 1990 and 2000, we find that FDI stock in LDCs tends to reduce the out-migration of individuals with tertiary and secondary education, but not the out-migration of individuals with only primary education. Instead, existing community of migrants has a dominant effect on the outmigration of individuals with primary education.

We consider this negative relationship between inward FDI and out-migration as the home effect of inward FDI. MNCs might offer higher wages than national firms in LDCs, which reduces the wage differential between LDCs and DCs. Or, FDI can create job opportunities in LDCs. As a result, prospective migrants in LDCs are more likely to stay in their home countries (Borjas, 1999). ${ }^{3}$ However, the home effect may not be as evident as an increase in activities of MNCs may 'westernise' LDCs, which in turn builds cultural and ideological links between an LDC and the parent country of MNCs (Sassen, 1988, 1993). We refer to this as the linkage effect of FDI, and the linkage effect encourages migration.

We attempt to distinguish between the home effect and the linkage effect in our estimations. Our results suggest that inward FDI has a stronger home effect on the out-migration of individuals with tertiary education than individuals with secondary education. Yet, the linkage effect seems to be stronger for the migration of individuals with secondary education than individuals with tertiary education.

Our results are of great interest to many LDC governments. Outflows of skilled labour are generally taken as a loss of human capital (often called 'brain drain') and may become an obstacle to economic growth (Wong and Yip, 1999; Beine et al., 2008); therefore, many LDCs typically employ certain migration restrictions to reduce such outflows. For instance, in the 1990s, if a Chinese student with a bachelor's degree planned to come to the US, the student either needed to complete a five-year employment obligation in China after obtaining the bachelor's degree or had to pay a 'fine' to the Ministry of Education. Although government policies might be effective in limiting skilled labour outflows temporarily, the creation of economic incentives through the operation of market forces, such as inward FDI, would be the more effective way to retain skilled workers in their home countries.

This research has at least two policy implications. First, immigration policy can focus on how the social and demographic characteristics of the population are affected. If we use Jasso and Rosenzweig

(2006) comprehensive survey of the US as an example, we see that, unlike our study, numerous policy interventions treat human capital as a secondary or non-existent concern. These findings suggest policy implications will need to expand to include the interaction of investment on existing policy.

Second, and related to FDI and human capital considerations, is how they influence many other factors related to immigration policy. Testable policy implications of this study could harness the use of data from countries that have immigrant surveys, such as the New Immigrant Survey. ${ }^{4}$ Surveys of this type use a panel design, and they allow for a substantial set of potential interactions between the FDI-human capital relation to acculturation, family life, financial assets, job history and more. 
The remainder of our paper is organised as follows: Section 2 describes potential links between FDI on international migration; Section 3 introduces our empirical specification and data; Section 4 discusses empirical results. Conclusions are offered in Section 5.

\section{Foreign Direct Investment And International Migration}

Neoclassical economic theory suggests that income or economic differentials across countries play a significant role in individuals' decision regarding migration as prospective migrants invariably compare benefits and costs of migrating to a foreign country. In other words, an individual takes into consideration expected earnings in the home country, expected earnings in the destination country, risks associated with migration such as living in an unfamiliar environment and also the fixed cost of the trip (Massey and Espinosa, 1997).

Conceptually, FDI can affect international migration through two channels (Sassen, 1988, 1993; Sauvant et al., 1993; Sanderson and Kentor, 2008). First, FDI can directly influence the likelihood of migration by changing employment opportunities in the home country and wage differentials between the home country and the destination country for prospective migrants. In addition, FDI can indirectly affect international migration through its impact on macroeconomic conditions, especially the economic development in the home country of prospective migrants. We will name these the 'home effect' when we discuss our empirical results. In general, if FDI improves the macroeconomic conditions of a country, it should decrease the likelihood of out-migration.

Second, FDI may strengthen the links between countries and help potential migrants better understand the culture and ideologies in the parent country of MNCs (the destination country for migrants), which encourages migration. This will be referred to as the 'linkage effect' in our future empirical discussions, and linkage effect tends to increase the likelihood of migration.

Borjas (1999) point out that inflows of foreign capital should increase the marginal product of labour as well as provide more employment opportunities, thus reducing the necessity of out-migration. The total foreign employment by affiliates of MNCs has been rising steadily over time, with an average growth rate of 5.5 per cent over the period of 1990-95, 9.8 per cent over the period of 1996-2000 and 6.7 per cent over the period of 2001-05. United Nations (2010) estimates that in 2009, the total foreign employment of MNCs reached 79.8 million, compared to 24.5 million in 1990. In some LDCs, the employment effect of FDI can be considerable. For example, the employment by maquiladoras accounted for 16 per cent of the total employment in manufacturing industries in Mexico in 1991 and 22.4 per cent in 2006 (United Nations, 1992; Federal Reserve Bank of Dallas, 2010).

In addition, wages offered by MNCs tend to be higher than wages offered by domestic firms. On average, the annual nominal wage offered by non-bank majority-owned affiliates of US MNCs in different host countries increased by 105 per cent between 1989 and 2004 to \$25,719 (Bureau of Economic Analysis 1989, 2004). The difference between wages offered by foreign affiliates of MNCs and national firms in LDCs is often striking. In Kenya, the wage offered by foreign service affiliates can be 75 per cent higher than wage offered by domestic service firms (Sauvant et al., 1993). As a result, there might be less incentive for international migration given a reduced wage differential between home and destination countries. Besides the better income prospects, the lion's share of employees in foreign affiliates, including employees at the management level, are recruited locally. Sauvant et al. (1993) argue that FDI can also influence out-migration by changing prospective migrants' expectations of professional achievement. The upward mobility or expectations of merit-based advancement in 
foreign firms, which are considered more stable than national firms, can also serve as an incentive for individuals to stay in the home country rather than engage in out-migration.

As recognised by most researchers, income differentials across countries are quite persistent, and the gap between high-income countries and low-income countries indeed has been widening over time. According to the World Bank, the real GDP per capita in high-income OECD countries rose from $\$ 17,913$ in 1984 to $\$ 28,191$ in 2006 (a 57 per cent increase), while the real GDP per capita in low-income countries rose from \$250 to \$345 (a 38 per cent increase). Such a persistent income differential brings about potential for international migration, and a low GDP per capita tends to be associated with a high out-migration rate. For example, the GDP per capita of El Salvador was approximately 8 per cent of the US GDP per capita in 1990, and the ratio of migrants from El Salvador in the US to the total population in El Salvador in 1990 was 4.93 per cent. The real GDP per capita of Spain in 1990 was 42 per cent of the US, and the ratio of migrants of Spain in the US to the total population in Spain was only 0.05 per cent (Department of Homeland Security, 1995; Maddison, 2003).

To narrow the income gap, which contributes to international migration, LDCs need to improve their economic growth rate. The World Bank categorises low-income countries as countries with a per capita gross national income (GNI) of $\$ 975$ or less and upper-middle-income countries as countries with a per capita GNI of $\$ 3,856$ or higher. For a low-income country with a constant economic growth rate of 5 per cent, it will take approximately 30 years for the country to become an upper-middle-income country; if a low-income country can have a 10 per cent economic growth rate, the time needed for this country to become an upper-middle-income country will be decreased in half to 14 years. ${ }^{5}$

Economic development is a complicated process, but in general, classical and new growth theories predict that physical capital accumulation and technological improvements are twin engines of economic growth (Solow, 1957; Romer, 1994). FDI has long been considered a vehicle transferring not only physical capital but also intangible assets such as better product design and better management skills. Consequently, FDI may also have a positive impact on macroeconomic conditions in LDCs, specifically economic growth, and in turn reduces international migration. ${ }^{6}$

In contrast, Sassen $(1988,1993)$ believes that capital mobility and internationalisation of production are actually migration-inducing factors. As Sassen (1993, p. 74) states, '[m]igrations do not just happen; they are produced. And migrations do not involve just any possible combination of countries; they are patterned'. Capital inflows have generated new conditions for international labour mobility; that is, rather than deterring out-migration, FDI has precisely the opposite effect. In manufacturing industries, as FDI 'exports' manufacturing jobs from DCs to LDCs, it can disrupt local communities and draw new segments into the labour force, particularly young women. This not only creates internal migration flows from rural to urban areas in LDCs, but also a 'mobilised' population that can migrate to foreign countries. Sassen shows that starting in the 1960s, there was a dramatic upsurge in migration from countries in Latin America and the Caribbean and Asia together with large flows of US investments into those regions.

Furthermore, FDI from industrialised countries to LDCs may 'westernise' their local employees and increase cultural and ideological distances between their local employees and their home communities. As a result, when these local employees leave affiliates of MNCs, they are less willing to return to their communities of origin. Instead, migrating to foreign countries becomes a better option given their cultural and ideological linkages with 
DCs. In summary, according to Sassen (1988), globalisation or increased international capital flows has created pools of people who can migrate as well as linkages between DCs and LDCs.

\section{Empirical Specification and Data Description}

\section{A. Empirical Specification}

Our study focuses on the relation between FDI and international migration in LDCs. Countries included in the sample and the time span of the study are solely determined by data availability. Our empirical specification takes the following form (see also Sanderson and Kentor, 2008):

$$
\text { migration }_{j i}^{e}=\alpha+\beta F D I_{i j, 1990}+\delta^{\prime} Z_{1990}+\varepsilon_{i j},(1)
$$

where $\Delta$ migration $_{j i}^{e}$ is the change in migration stock from country $j$ to country $i$ by education level $e$ between 1990 and 2000. We use the migration data from Docquier and Marfouk (2004), which will be discussed in detail in the following section. Our main control variable of interest, $F D I_{i j, 1990,}$ is the inward FDI stock in country $j$ from country $i$ as of $1990 .{ }^{7} Z$ represents a vector of other control variables capturing relative benefits and costs of migration (Greenwood, 1997; Massey and Espinosa, 1997). Variables included in $Z$ will also be described below. We focus on the migration from LDCs to DCs for two reasons. First, the pattern of migration from LDCs to DCs can be qualitatively different from the pattern of migration from LDCs to DCs. Second, as mentioned previously, LDCs generally have more concerns over the out-migration of individuals, especially the out-migration of individuals with higher education. Although it is difficult to perfectly define DCs and LDCs, high-income OECD countries will serve as a group of DCs in this study based on income and other factors such as political conditions and infrastructure. ${ }^{8}$ Other countries are LDCs.

\section{B. MIGRATION AND FDI VARIABLES}

The empirical literature of international migration has been slow to develop due to a lack of quality data. Carrington and Detragiache (1998) point out that the main obstacles are insufficient data and inconsistent records. They made the first major attempt to estimate the migration rates in LDCs by three different education levels. Docquier and Marfouk (2004)extend and improve upon the pioneering work of Carrington and Detragiache by estimating migration from home countries to individual OECD destination countries in 1990 and 2000 with information on education levels of the migrants. Docquier and Marfouk define the stock of emigrants from a home country as individuals aged 25 and above with a certain level of education and born in the home country but living in another country as of 1990 and 2000. They separate the migrants by three levels of education, namely primary, secondary and tertiary education. ${ }^{9}$ However, they do not consider emigrants' occupation, where the education took place or when the migrants arrived in the country of destination. Their estimates cover about 88.8 per cent of the OECD stock of adult immigrants in 1990 and 92.7 per cent in 2000.

To better assess the magnitude of migration, Docquier and Marfouk (2004) standardise the stock of emigrants with a certain level of education by the total population with the same level of education in the emigrants' home country in 1990 and 2000, respectively. In other words, the migration from country $j$ to country $i$ is measured as: migration $_{j i, t}^{e}=\operatorname{stock}_{j i, t}^{e} /$ pop $_{j, t}^{e}$ for $i \neq j$, 
where: $t=1990$ and 2000, $e=$ \{primary, secondary and tertiary education\}; ${ }^{\text {stock }}{ }_{j i, t}^{e}$ is the number of individuals aged 25 years or above as of year $t$ with education level $e$, who live in country $i$, but who were born in country $j$; $\operatorname{pop}_{j, t}^{e}$ stands for the total population in country jin year $t$ with education level $e$. This ratio $\left(\right.$ stock $_{j i, t}^{e} /$ pop $\left._{j, t}^{e}\right)$ captures the relative magnitude of migration from country $j$ to country $i .10$ Docquier and Marfouk emphasise the migration measure when $e=$ tertiary education as it represents the magnitude of the 'brain drain'. In our paper, we look at the migration measure for all three different levels of education. The migration data in Docquier and Marfouk (2004) can be obtained from the Research Program for International Migration \& Development from World Bank.

As mentioned previously, our dependent variable in the regressions is the change in migration stock, that is: Amigration $_{j i}^{e}=$ migration $_{j i, 2000}^{e}-$ migration $_{j i, 1990}^{e}$. The migration data in Docquier and Marfouk (2004) measure the migrants stock as of 1990 or 2000 . So they do not represent the actual migration that occurred in 1990 or 2000 . People who migrated from $j$ to $i$ before 1990 are included in both $^{\text {migration }}{ }_{j i, 1990}^{e}$ and mi gration $_{j i, 2000}^{e}$. To provide an accurate estimation of the effect of FDI on international migration, we take the difference between mi gration $_{j i, 2000}^{e}$ and migration $_{j i, 1990}^{e}$, so that we can focus on the net migration that occurred between 1990 and 2000 from $j$ to $i$ and how inward FDI affects this change.

Foreign direct investment $(F D I)$ is the expression of interest in ownership and control by a foreign investor in an existing enterprise. The Bureau of Economic Analysis defines this interest as the foreign investor acquiring at least 10 per cent ownership of the domestic enterprise. The same numerical guideline is used by the International Monetary Fund (IMF). In our study, the FDI variable is measured as the level of inward FDI stock in country $j$ from country $i$. The advantages of employing FDI stock over FDI flows are twofold.

First, as the FDI stock is a cumulative measure of FDI flows over years, it provides a better estimate of the longterm effect of FDI on international migration. Second, short-term flows can fluctuate markedly from one year to another, which lead to very different results of the impact of FDI on migration. FDI stock is more stable and generates more reliable results. To better assess the importance of FDI in a host country, our FDI stock measure is standardised as a share of country j's GDP. Data on FDI stock are obtained from the International Direct Investment Statistics database from SourceOECD.

Based on the data availability of migration stock in both 1990 and 2000 and bilateral FDI in 1990, we are able to obtain a sample of 14 OECD countries as destination countries and 19 LDCs as home countries with 82 observations. Most LDCs in our sample have out-migration to three or five destination countries. Given that none of the 19 LDCs dominate others in terms of migration flows, a potential over-representation of some home countries should not be a concern in our sample. Consequently, our empirical results will not be distorted by the out-migration pattern of one or two LDCs. A list of these countries is provided in Table A1 in the Appendix A.

\section{Other Control Variables}

Generally speaking, individuals tend to migrate to a foreign country with better income prospects, better employment opportunities or more stable economic and political regimes. We include variables related to such economic and political conditions in the $\boldsymbol{Z}$ vector. These variables represent the 'pull' and 'push' factors 
commonly used in the international migration literature (Greenwood and McDowell, 1991; Obstfeld and

Rogoff, 1996; Aroca and Maloney, 2005). They refer to pull-factors in the country of destination that attract migrants and push-factors that drive people to leave the home country. Our included economic factors are as follows: the income level in the destination country and the home country (income destination, income home), unemployment rate (unemployment destination, unemployment home) and inflation rate (inflation destination, inflation home).

A key factor explaining international migration is the income gap between the home country and the destination country. Consequently, a large out-migration tends to be associated with a low home income and a high foreign income. The unemployment rate can represent the availability of jobs in home and destination countries. A high unemployment rate in the home country and a low unemployment rate in the destination country indicate that there might be a large pool of prospective migrants who are not able to find jobs at home and are potentially attracted by the abundant job opportunities in the country of destination. The inflation rate can affect the perceived relative benefit of migration. A high inflation in the home country and a low inflation rate in the destination country decrease the purchasing power of home income relative to the purchasing power of foreign income for prospective migrants and thus induce out-migration. The income level is measured as the log value of real GDP per capita. The inflation rate is defined as the percentage change in the consumer price index. These data are obtained from World Development Indicators (WDIs) published by the World Bank, World Economic Outlook (WEO) series published by the IMF and the International Labor Organisation (ILO) database operated by the ILO Bureau of Statistics. We also include a trade openness variable (openness) in our empirical study, which is measured by the bilateral trade value between country $i$ and $j$ as a share of country $j$ 's GDP. Sanderson and Kentor (2008) use trade value to measure the extent to which a country is integrated into the world economy. The bilateral trade data come from the Monthly International Trade database from the OECD. ${ }^{11}$

Our political condition variable is a measure of political freedom (political freedom). It is an average of two scores on political rights and civil liberties. The data are collected from different issues of Freedom in the World, published by the Freedom House (http://www.freedomhouse.org). Countries whose combined average ratings for political rights and civil liberties fall between 1.0 and 2.5 are designated 'free'; between 3.0 and 5.5 'partly free'; and between 5.5 and 7.0 'not free'. Therefore, a lower average score represents political freedom, and a higher average score indicates that the country has less political freedom. We take a log difference of political freedom between the home country and the destination country to obtain a measure of relative political freedom. The larger the value of this variable, the more political freedom the destination country has relative to the home country. We expect the relative political freedom to have a positive impact on the out-migration from home because more political freedom or a better democratic system in the destination country tends to attract migrants. In addition, countries with better political rights and civil liberties may have less restrictive immigration policies.

Certain cultural and geographical variables are also included in our study as proxies for risks associated with migration and the cost of moving - the log value of the distance between the home country and the destination country (distance); whether home and destination countries share a common language (common language); whether the home country and the destination country share a common border (common border); whether a country is landlocked (landlock destination, landlock home); and geographical location dummies for countries in our sample. The data are from Centre D'Etudes Prospectives Et D'Informations Internationales (CEPII). Common language and common border are dummy variables taking the value of one if the home country and the destination country share a common language or share a common border, respectively, zero 
otherwise. ${ }^{12}$ Similarly, landlock is a dummy variable taking the value of one if the country is landlocked, zero otherwise. The distance between two countries is typically used as a proxy for the fixed cost of a trip. So a long distance between the home country and the destination country tends to reduce international migration. Home and destination countries that share a common border or a common language may also share a similar culture. Prospective migrants will not feel that they are in a completely new environment and are more likely to stay and obtain a good job in the destination country. In addition, sharing a common border means a short distance between the home country and the destination country.

We expect that a common border and a common language both increase the likelihood of migration. We use the landlock dummy variable as a measure for general ease of transportation. As Sassen (1988) argues, seaports that facilitate the transportation of goods from one country to another can also facilitate the movement of people. We expect that a non-landlocked country might have more out-migration than a landlocked country, and similarly, a non-landlocked destination country might receive more migrants than a landlocked destination country. Summary statistics for all variables are provided in Table $\mathbf{1}$.

Table 1. Descriptive Statistics

\begin{tabular}{|c|c|c|c|c|}
\hline Variable & Mean & Standard Deviation & Minimum & Maximum \\
\hline Tertiary education migration $_{1990}$ & 0.0222 & 0.0775 & 0 & 0.6748 \\
\hline Secondary education migration $_{1990}$ & 0.0027 & 0.0059 & 0 & 0.0311 \\
\hline Primary education migration ${ }_{1990}$ & 0.0020 & 0.0067 & 0 & 0.0479 \\
\hline Tertiary education migration ${ }_{2000}$ & 0.0167 & 0.0534 & 0 & 0.4555 \\
\hline Secondary education migration 2000 & 0.0029 & 0.0054 & 0 & 0.0253 \\
\hline Primary education migration 2000 & 0.0018 & 0.0056 & 0 & 0.0388 \\
\hline $\mathrm{FDI}_{1990}$ & 0.0224 & 0.0845 & 0 & 0.7322 \\
\hline Political Freedom & -0.9188 & 0.4148 & -1.9459 & 0 \\
\hline Distance (in log) & 8.7933 & 0.7964 & 5.7834 & 9.8152 \\
\hline Common language & 0.1829 & 0.3890 & 0 & 1 \\
\hline Common border & 0.0122 & 0.1104 & 0 & 1 \\
\hline Landlock destination & 0.0488 & 0.2167 & 0 & 1 \\
\hline Landlock source & 0.1463 & 0.3556 & 0 & 1 \\
\hline Income $_{1990}$ destination (in log) & 10.070 & 0.3232 & 8.9831 & 10.735 \\
\hline Income $_{1990}$ source (in log) & 7.9637 & 0.9309 & 5.8587 & 9.7925 \\
\hline Unemployment ${ }_{1990}$ destination (\%) & 6.3695 & 2.5467 & 0.5000 & 11.400 \\
\hline Unemployment ${ }_{1990}$ source (\%) & 6.1354 & 3.3423 & 1.7000 & 15.800 \\
\hline Trade $_{1990}$ & 0.0034 & 0.0066 & 0 & 0.0403 \\
\hline Inflation $_{1990}$ destination (\%) & 5.2955 & 2.1527 & 2.4540 & 10.377 \\
\hline Inflation $_{1990}$ source (\%) & 484.56 & 993.92 & 2.6180 & 2947.7 \\
\hline
\end{tabular}

Notes:

(i) FDI, foreign direct investment.

(ii) The variables of tertiary education migration, secondary education migration and primary education migration represent the individuals 25 years of age or above with tertiary, secondary and primary education, respectively, who were born in the source country and live in the destination country relative to the population in the source country. The migration data are from Docquier and Marfouk (2004). (iii) The FDI variable is measured as the level of inward FDI stock in the source country from the destination country. (iv) The data are 
from the International Direct Investment Statistics database (OECD). (v) Political freedom is a log difference of political freedom between the home country and the destination country. The data are collected from different issues of Freedom in the World. (vi) The distance variable is defined as distance (in log) between two countries' most important cities (in terms of population). (vii) Common language, common border, landlock destination and landlock source are dummy variables. They are obtained from Centre D'Etudes Prospectives EI D'Informations Internationales (CEPII). (viii) The variables of income (real GDP per capita), unemployment rates, trade openness and inflation rates are from the World Development Indicators.

\section{Empirical Estimation and Results}

Before presenting our empirical results, we mention a few general estimation issues. First, we use the seemingly unrelated regressions (SUR) technique for estimation. Our SUR system includes three regressions. Dependent variables in these three regressions are change of migration of individuals with tertiary education, secondary education and primary education, respectively. The SUR system estimates several regressions simultaneously, allowing for potential correlation among the error terms. Given that there can be some unobserved factors that affect the out-migration of individuals with different levels of education at the same time, SUR is an appropriate technique for our model. Second, heteroscedasticity can be important across countries, and all our estimates use White-adjusted standard errors.

As mentioned previously, there is no reverse causality for our cross-sectional model given the time lag between measures of our dependent and independent variables (see also Docquier and Lodigiani, 2010). Several control variables in the regression are time-invariant, such as distance and geographical contiguity. As a result, the coefficients on those variables should not suffer from endogeneity caused by the existence of unobservable factors influencing migration. With that said, to better identify the effect of our main variable of interest and control for endogeneity due to the existence of unobservables affecting both migration and FDI, an instrumentation methodology is also adopted (Rajan and Subramanian, 2008). ${ }^{13}$ For comparison, we report empirical results of both regular SUR and three-stage least squares (3SLS). However, our discussion is mainly based on estimated coefficients from 3SLS.

\section{A. The Effects Of Fdi And Social Capital On International Migration}

Table 2 contains the results of the estimation of equation (1). We refer to the three regressions in the SUR and 3SLS systems by different levels of education as tertiary regression, secondary regression and primary regression. Panel A presents results of the tertiary regression with different specifications. All control variables have the expected signs. Political freedom, income in the destination country and openness are significant factors affecting migration of individuals with tertiary education. We provide corresponding secondary and primary regression results in panels $B$ and $C$, respectively. The estimated coefficients on control variables are qualitatively similar to those in the tertiary regressions. In the interest of brevity, we only report the estimated coefficients on FDI in panels B and C. Other coefficients from secondary and primary regressions are available upon request.

Table 2. Foreign Direct Investment (FDI) and Migration with Different Levels of Education

\begin{tabular}{|c|c|c|c|c|c|c|c|c|c|c|}
\hline & SUR1 & SUR2 & SUR3 & SUR4 & SUR5 & 3SLS1 & 3SLS2 & 3SLS3 & 3SLS4 & 3SLS5 \\
\hline $\begin{array}{l}\text { Panel A: Tertiary } \\
\text { education migration }\end{array}$ & & & & & & & & & & \\
\hline
\end{tabular}




\begin{tabular}{|c|c|c|c|c|c|c|c|c|c|c|}
\hline $\mathrm{FDI}_{1990}$ & $\begin{array}{l}-0.28134 \\
* * * \\
(0.01352 \\
)\end{array}$ & $\begin{array}{l}-0.29303 \\
* * * \\
(0.01245 \\
)\end{array}$ & $\begin{array}{l}-0.28069 \\
* * * \\
(0.01368 \\
)\end{array}$ & $\begin{array}{l}-0.281 \\
40^{* * *} \\
(0.013 \\
51)\end{array}$ & $\begin{array}{l}-0.283 \\
34^{* * *} \\
(0.014 \\
37)\end{array}$ & $\begin{array}{l}-0.2760 \\
5^{* * *} \\
(0.017)\end{array}$ & $\begin{array}{l}-0.2900 \\
2^{* * *} \\
(0.016)\end{array}$ & $\begin{array}{l}-0.275 \\
07^{* * *} \\
(0.018 \\
)\end{array}$ & $\begin{array}{l}-0.275 \\
20^{* * *} \\
(0.017 \\
)\end{array}$ & $\begin{array}{l}-0.27 \\
943^{* *} \\
* \\
(0.019 \\
)\end{array}$ \\
\hline Common language & $\begin{array}{l}0.00029 \\
(0.00305 \\
)\end{array}$ & $\begin{array}{l}-0.00331 \\
(0.00289 \\
)\end{array}$ & $\begin{array}{l}0.00065 \\
(0.00311 \\
)\end{array}$ & $\begin{array}{l}0.0002 \\
5 \\
(0.003 \\
05)\end{array}$ & $\begin{array}{l}0.0001 \\
8 \\
(0.003 \\
11)\end{array}$ & $\begin{array}{l}0.0000 \\
(0.003)\end{array}$ & $\begin{array}{l}-0.0035 \\
3 \\
(0.003)\end{array}$ & $\begin{array}{l}0.0004 \\
(0.003 \\
)\end{array}$ & $\begin{array}{l}-0.000 \\
08 \\
(0.003 \\
)\end{array}$ & $\begin{array}{l}0.000 \\
07 \\
(0.003 \\
)\end{array}$ \\
\hline Distance & $\begin{array}{l}-0.00173 \\
(0.00155 \\
)\end{array}$ & $\begin{array}{l}-0.00055 \\
(0.00144 \\
)\end{array}$ & $\begin{array}{l}-0.00189 \\
(0.00168 \\
)\end{array}$ & $\begin{array}{l}-0.001 \\
55 \\
(0.001 \\
60)\end{array}$ & $\begin{array}{l}-0.001 \\
8 \\
(0.001 \\
57)\end{array}$ & $\begin{array}{l}-0.0019 \\
5 \\
(0.002)\end{array}$ & $\begin{array}{l}-0.0005 \\
8 \\
(0.001)\end{array}$ & $\begin{array}{l}-0.002 \\
18 \\
(0.002 \\
)\end{array}$ & $\begin{array}{l}-0.001 \\
77 \\
(0.002 \\
)\end{array}$ & $\begin{array}{l}-0.00 \\
2 \\
(0.002 \\
1\end{array}$ \\
\hline Political freedom & $\begin{array}{l}0.00549 * \\
(0.00294 \\
)\end{array}$ & $\begin{array}{l}0.00919 * \\
* * \\
(0.00277 \\
)\end{array}$ & $\begin{array}{l}0.00501 \\
(0.00306 \\
)\end{array}$ & $\begin{array}{l}0.0054 \\
4^{*} \\
(0.002 \\
94)\end{array}$ & $\begin{array}{l}0.0060 \\
9^{*} \\
(0.003 \\
11)\end{array}$ & $\begin{array}{l}0.00536 \\
* \\
(0.003)\end{array}$ & $\begin{array}{l}0.00929 \\
* * * \\
(0.003)\end{array}$ & $\begin{array}{l}0.0047 \\
8 \\
(0.003 \\
)\end{array}$ & $\begin{array}{l}0.0053 \\
1^{*} \\
(0.003 \\
)\end{array}$ & $\begin{array}{l}0.005 \\
77^{*} \\
(0.003 \\
)\end{array}$ \\
\hline Landlock destination & $\begin{array}{l}-0.00784 \\
(0.00585 \\
)\end{array}$ & $\begin{array}{l}-0.00314 \\
(0.00540 \\
)\end{array}$ & $\begin{array}{l}-0.00789 \\
(0.00584 \\
)\end{array}$ & $\begin{array}{l}-0.008 \\
83 \\
(0.006 \\
29)\end{array}$ & $\begin{array}{l}-0.007 \\
27 \\
(0.006 \\
08)\end{array}$ & $\begin{array}{l}-0.0080 \\
8 \\
(0.006)\end{array}$ & $\begin{array}{l}-0.0028 \\
6 \\
(0.005)\end{array}$ & $\begin{array}{l}-0.008 \\
13 \\
(0.006 \\
)\end{array}$ & $\begin{array}{l}-0.008 \\
92 \\
(0.006 \\
)\end{array}$ & $\begin{array}{l}-0.00 \\
781 \\
(0.006 \\
)\end{array}$ \\
\hline Landlock source & $\begin{array}{l}-0.00064 \\
(0.00295 \\
)\end{array}$ & $\begin{array}{l}-0.00304 \\
(0.00270 \\
)\end{array}$ & $\begin{array}{l}-0.0002 \\
(0.00305 \\
)\end{array}$ & $\begin{array}{l}-0.000 \\
69 \\
(0.002 \\
95)\end{array}$ & $\begin{array}{l}-0.000 \\
49 \\
(0.002 \\
97)\end{array}$ & $\begin{array}{l}-0.0005 \\
5 \\
(0.003)\end{array}$ & $\begin{array}{l}-0.0028 \\
6 \\
(0.003)\end{array}$ & $\begin{array}{l}-0.000 \\
01 \\
(0.003 \\
)\end{array}$ & $\begin{array}{l}-0.000 \\
59 \\
(0.003 \\
)\end{array}$ & $\begin{array}{l}-0.00 \\
046 \\
(0.003 \\
)\end{array}$ \\
\hline $\begin{array}{l}\text { Income }_{1990} \\
\text { destination }\end{array}$ & $\begin{array}{l}0.01196 * \\
* * \\
(0.00380 \\
)\end{array}$ & $\begin{array}{l}0.00972 * \\
* \\
(0.00383 \\
)\end{array}$ & $\begin{array}{l}0.01115^{*} \\
* \\
(0.00515 \\
)\end{array}$ & $\begin{array}{l}0.0119 \\
4^{* * *} \\
(0.003 \\
79)\end{array}$ & $\begin{array}{l}0.0126 \\
0 * * * \\
(0.003 \\
95)\end{array}$ & $\begin{array}{l}0.01200 \\
* * * \\
(0.004)\end{array}$ & $\begin{array}{l}0.00955 \\
* * \\
(0.004)\end{array}$ & $\begin{array}{l}0.0113 \\
0 * * \\
(0.005 \\
)\end{array}$ & $\begin{array}{l}0.0119 \\
5^{* * *} \\
(0.004 \\
)\end{array}$ & $\begin{array}{l}0.012 \\
41^{* * *} \\
(0.004 \\
)\end{array}$ \\
\hline Income $_{1990}$ home & $\begin{array}{l}-0.00146 \\
(0.00135 \\
)\end{array}$ & $\begin{array}{l}-0.00276 \\
* * \\
(0.00127 \\
)\end{array}$ & $\begin{array}{l}-0.00157 \\
(0.00137 \\
)\end{array}$ & $\begin{array}{l}-0.001 \\
49 \\
(0.001 \\
35)\end{array}$ & $\begin{array}{l}-0.001 \\
43 \\
(0.001 \\
49)\end{array}$ & $\begin{array}{l}-0.0015 \\
1 \\
(0.001)\end{array}$ & $\begin{array}{l}-0.0026 \\
9^{* *} \\
(0.001)\end{array}$ & $\begin{array}{l}-0.001 \\
64 \\
(0.001 \\
)\end{array}$ & $\begin{array}{l}-0.001 \\
55 \\
(0.001 \\
)\end{array}$ & $\begin{array}{l}-0.00 \\
144 \\
(0.002 \\
)\end{array}$ \\
\hline $\begin{array}{l}\text { Unemployment }{ }_{1990} \text { destina } \\
\text { tion }\end{array}$ & $\begin{array}{l}-0.00071 \\
(0.00047 \\
)\end{array}$ & $\begin{array}{l}-0.00027 \\
(0.00045 \\
)\end{array}$ & $\begin{array}{l}-0.00075 \\
(0.00050 \\
)\end{array}$ & $\begin{array}{l}-0.000 \\
72 \\
(0.000 \\
47)\end{array}$ & $\begin{array}{l}-0.000 \\
66 \\
(0.000 \\
49)\end{array}$ & $\begin{array}{l}-0.0007 \\
(0.000)\end{array}$ & $\begin{array}{l}-0.0002 \\
6 \\
(0.000)\end{array}$ & $\begin{array}{l}-0.000 \\
73 \\
(0.001 \\
)\end{array}$ & $\begin{array}{l}-0.000 \\
71 \\
(0.000 \\
)\end{array}$ & $\begin{array}{l}-0.00 \\
067 \\
(0.000 \\
)\end{array}$ \\
\hline $\begin{array}{l}\text { Unemployment } 1990 \\
\text { home }\end{array}$ & $\begin{array}{l}-0.00024 \\
(0.00035 \\
)\end{array}$ & $\begin{array}{l}0.00003 \\
(0.00032 \\
)\end{array}$ & $\begin{array}{l}-0.00022 \\
(0.00035 \\
)\end{array}$ & $\begin{array}{l}-0.000 \\
21 \\
(0.000 \\
36)\end{array}$ & $\begin{array}{l}-0.000 \\
23 \\
(0.000 \\
37)\end{array}$ & $\begin{array}{l}-0.0002 \\
5 \\
(0.000)\end{array}$ & $\begin{array}{l}0.00009 \\
(0.000)\end{array}$ & $\begin{array}{l}-0.000 \\
23 \\
(0.000 \\
)\end{array}$ & $\begin{array}{l}-0.000 \\
23 \\
(0.000 \\
)\end{array}$ & $\begin{array}{l}-0.00 \\
023 \\
(0.000 \\
)\end{array}$ \\
\hline Trade $_{1990}$ & - & $\begin{array}{l}0.82906 * \\
* * \\
(0.18519 \\
)\end{array}$ & - & - & - & - & $\begin{array}{l}0.84127 \\
* * * \\
(0.191)\end{array}$ & - & - & - \\
\hline $\begin{array}{l}\text { Inflation }_{1990} \\
\text { destination }\end{array}$ & - & - & $\begin{array}{l}-0.00013 \\
(0.00071 \\
)\end{array}$ & - & - & - & - & $\begin{array}{l}-0.000 \\
1 \\
(0.001 \\
)\end{array}$ & - & - \\
\hline Inflation $_{1990}$ home & - & - & $\begin{array}{l}0.00000 \\
(0.00000 \\
)\end{array}$ & - & - & - & - & $\begin{array}{l}0.0000 \\
(0.000 \\
)\end{array}$ & - & - \\
\hline
\end{tabular}




\begin{tabular}{|c|c|c|c|c|c|c|c|c|c|c|}
\hline Common border & - & - & - & $\begin{array}{l}0.0048 \\
8 \\
(0.011 \\
38)\end{array}$ & - & - & - & - & $\begin{array}{l}0.0043 \\
9 \\
(0.011 \\
)\end{array}$ & - \\
\hline Constant & $\begin{array}{l}-0.08141 \\
* * \\
(0.037)\end{array}$ & $\begin{array}{l}-0.06169 \\
(0.040)\end{array}$ & $\begin{array}{l}-0.07102 \\
(0.051)\end{array}$ & $\begin{array}{l}-0.082 \\
63^{* *} \\
(0.037 \\
)\end{array}$ & $\begin{array}{l}-0.086 \\
65^{* *} \\
(0.038 \\
)\end{array}$ & $\begin{array}{l}-0.0797 \\
0 * * \\
(0.037)\end{array}$ & $\begin{array}{l}-0.0609 \\
5 \\
(0.040)\end{array}$ & $\begin{array}{l}-0.070 \\
06 \\
(0.052 \\
)\end{array}$ & $\begin{array}{l}-0.080 \\
55^{* *} \\
(0.037 \\
)\end{array}$ & $\begin{array}{l}-0.08 \\
347^{* *} \\
(0.039 \\
)\end{array}$ \\
\hline Observations & 82 & 81 & 82 & 82 & 82 & 80 & 79 & 80 & 80 & 80 \\
\hline$R^{2}$ & 0.8699 & 0.8959 & 0.8705 & 0.8702 & 0.8705 & 0.871 & 0.898 & 0.8717 & 0.8711 & $\begin{array}{l}0.871 \\
4\end{array}$ \\
\hline \multicolumn{11}{|l|}{$\begin{array}{l}\text { Panel B: Secondary } \\
\text { education migration }\end{array}$} \\
\hline $\mathrm{FDI}_{1990}$ & $\begin{array}{l}-0.00892 \\
* * * \\
(0.00183 \\
)\end{array}$ & $\begin{array}{l}-0.00922 \\
* * * \\
(0.00186 \\
)\end{array}$ & $\begin{array}{l}-0.00833 \\
* * * \\
(0.00181 \\
)\end{array}$ & $\begin{array}{l}-0.008 \\
96 * * * \\
(0.001 \\
77)\end{array}$ & $\begin{array}{l}-0.008 \\
97 * * * \\
(0.001 \\
92)\end{array}$ & $\begin{array}{l}-0.0082 \\
9 * * * \\
(0.002)\end{array}$ & $\begin{array}{l}-0.0082 \\
3 * * * \\
(0.002)\end{array}$ & $\begin{array}{l}-0.007 \\
10 * * * \\
(0.002 \\
)\end{array}$ & $\begin{array}{l}-0.007 \\
80 * * * \\
(0.002 \\
)\end{array}$ & $\begin{array}{l}-0.00 \\
762 * * \\
* \\
(0.002 \\
)\end{array}$ \\
\hline$R^{2}$ & 0.3084 & 0.3262 & 0.3402 & 0.3527 & 0.3276 & 0.3162 & 0.3335 & 0.3467 & 0.3582 & $\begin{array}{l}0.339 \\
1\end{array}$ \\
\hline \multicolumn{11}{|l|}{$\begin{array}{l}\text { Panel C: Primary } \\
\text { education migration }\end{array}$} \\
\hline $\mathrm{FDI}_{1990}$ & $\begin{array}{l}-0.01007 \\
* * * \\
(0.00112 \\
)\end{array}$ & $\begin{array}{l}-0.01049 \\
* * * \\
(0.00112 \\
)\end{array}$ & $\begin{array}{l}-0.01018 \\
* * * \\
(0.00111 \\
)\end{array}$ & $\begin{array}{l}-0.010 \\
09 * * * \\
(0.001 \\
09)\end{array}$ & $\begin{array}{l}-0.010 \\
80 * * * \\
(0.001 \\
17)\end{array}$ & $\begin{array}{l}-0.0105 \\
1 * * * \\
(0.001)\end{array}$ & $\begin{array}{l}-0.0109 \\
5 * * * \\
(0.001)\end{array}$ & $\begin{array}{l}-0.011 \\
06 * * * \\
(0.001 \\
)\end{array}$ & $\begin{array}{l}-0.010 \\
24 * * * \\
(0.001 \\
)\end{array}$ & $\begin{array}{l}-0.01 \\
141 * * \\
* \\
(0.002 \\
)\end{array}$ \\
\hline$R^{2}$ & 0.6378 & 0.6564 & 0.652 & 0.6578 & 0.6523 & 0.6382 & 0.656 & 0.6499 & 0.6586 & $\begin{array}{l}0.651 \\
8\end{array}$ \\
\hline
\end{tabular}

Notes:

(i) Standard errors in brackets.

(ii) $* * *, * *, *$ Significant at $1 \%, 5 \%$ and 10\%, respectively. (iii) SUR5 includes regional dummies (South Asia and West European countries). (iv) The set of instrumental variables for the three-stage least squares regressions (3SLS) is as follows: the log value of land area in host country, domestic credit provided by banking sector in host country as a share of GDP and double taxation treaty, which is a dummy variable indicating a double taxation treaty governing 'income and capital' in place between host and parent country.

Theoretically, good instruments should be ones correlating with the endogenous variable, but not with the error term. In practice, ideal instruments may be hard to find. Following previous literature and also taking into consideration of data availability, our instruments for FDI include host country's land area (Borensztein et al., $\underline{\mathbf{1 9 9 8}}$ ), host country's domestic credit and double taxation treaty signed by the host and home of FDI (di Giovanni, 2005; Stein and Daude, 2007). Domestic credit is host domestic credit provided by the banking sector as a share of GDP. Double taxation treaty is a dummy variable indicating tax treaty governing income and capital in place between host and home countries of FDI. ${ }^{14}$ We perform several tests to determine whether the instruments are valid. The results are presented in Table $\mathbf{3}$.

Table 3. Diagnostic Tests on Instrumental Variables

\section{Variables}

3SLS1

3SLS2

3SLS3

3SLS4 3SLS5 


\begin{tabular}{|c|c|c|c|c|c|}
\hline \multicolumn{6}{|l|}{$\begin{array}{l}\text { Panel A: First stage for foreign direct } \\
\text { investment (FDI) }\end{array}$} \\
\hline $\log ($ Land area) & $\begin{array}{l}-0.1794 * * * \\
(0.0251)\end{array}$ & $\begin{array}{l}-0.1858 * * * \\
(0.0258)\end{array}$ & $\begin{array}{l}-0.1894^{* * *} \\
(0.0305)\end{array}$ & $\begin{array}{l}0.1808 * * * \\
(0.0252)\end{array}$ & $\begin{array}{l}-0.1387^{* * *} \\
(0.0294)\end{array}$ \\
\hline $\log ($ Land area) squared & $\begin{array}{l}0.0070 * * * \\
(0.0010)\end{array}$ & $\begin{array}{l}0.0073 * * * \\
(0.0011)\end{array}$ & $\begin{array}{l}0.0075^{* * *} \\
(0.0014)\end{array}$ & $\begin{array}{l}0.0071 * * * \\
(0.0010)\end{array}$ & $\begin{array}{l}0.0055^{* * *} \\
(0.0012)\end{array}$ \\
\hline Double taxation treaty & $\begin{array}{l}0.0226 \\
(0.0147)\end{array}$ & $\begin{array}{l}0.0263 * \\
(0.0155)\end{array}$ & $\begin{array}{l}0.0244^{*} \\
(0.0148)\end{array}$ & $\begin{array}{l}0.0218 \\
(0.0147)\end{array}$ & $\begin{array}{l}0.0264 * \\
(0.0142)\end{array}$ \\
\hline Domestic credit & $\begin{array}{l}0.0007^{*} \\
(0.0005)\end{array}$ & $\begin{array}{l}0.0008^{*} \\
(0.0005)\end{array}$ & $\begin{array}{l}0.0007 \\
(0.0006)\end{array}$ & $\begin{array}{l}0.0008^{*} \\
(0.0005)\end{array}$ & $\begin{array}{l}0.0016^{* * *} \\
(0.0005)\end{array}$ \\
\hline Other control variables & Yes & Yes & Yes & Yes & Yes \\
\hline$R^{2}$ & 0.6820 & 0.6908 & 0.6918 & 0.6863 & 0.7092 \\
\hline Number of Obs & 80 & 79 & 80 & 80 & 80 \\
\hline \multicolumn{6}{|l|}{$\begin{array}{l}\text { Panel B: Diagnostic tests for the original } \\
\text { IVs }\end{array}$} \\
\hline$F$ test of excl. inst. & $20.29 * * *$ & $18.97^{* * *}$ & $19.77^{* * *}$ & $20.42 * * *$ & $19.80 * * *$ \\
\hline Sargan overidentification statistics & 14.495 & 14.675 & 21.436 & 16.995 & 9.162 \\
\hline Sargan overidentification $p$-value & 0.2702 & 0.2597 & 0.0444 & 0.1498 & 0.4225 \\
\hline \multicolumn{6}{|l|}{$\begin{array}{l}\text { Panel C: Exclusion restriction test for } \\
\text { the original IVs }\end{array}$} \\
\hline $\begin{array}{l}\text { Are the coefficients on the original } \\
\text { IVs significant in the migration } \\
\text { regressions? }\end{array}$ & No & No & No & No & No \\
\hline $\begin{array}{l}\text { Sargan overidentification statistics } \\
\text { for the second set of IVs }\end{array}$ & 4.012 & 2.345 & 3.149 & 3.132 & 4.012 \\
\hline $\begin{array}{l}\text { Sargan overidentification } p \text {-value } \\
\text { for the second set of IVs }\end{array}$ & 0.2602 & 0.5040 & 0.3692 & 0.3717 & 0.2602 \\
\hline
\end{tabular}

Notes:

(i) Standard errors in brackets.

(ii) ${ }^{* * *}$ and $*$ Significant at $1 \%$ and $10 \%$, respectively. (iii) The diagnostic tests are based on the 3SLS regressions in Table 2. (iv) The set of instrumental variables is as follows: the log value of land area in host country, domestic credit provided by banking sector in host country as a share of GDP, and double taxation treaty which is a dummy variable indicating a double taxation treaty governing 'income and capital' in place between host and parent country.

(v) ${ }^{\text {T}}$ The second set of instruments for the exclusion restriction test is $B E R J$ and $B I T$, where $B E R I$ is a measure of host country business climate based on surveys and published by BERI, Inc, and $B I T$ is a dummy variable indicating a bilateral investment treaty in place between host and parent country. The null hypothesis of the exclusion restriction is that, conditional on the controls, the first set of instrument variables is not significant in the migration regressions. The null hypothesis of the overidentification test is that the second set of instrumental variables is exogenous in the migration regressions.

We find a strong first-stage relationship between our instruments and FDI stock (see panel A, Table $\mathbf{3}$ ). These first-stage regressions show instruments as a group having a significant impact on FDI stock. An F-test can be applied to see whether our instruments are relevant. The null hypothesis of this F-test is that coefficients on instruments in the first-stage regression are jointly zero. A rule of thumb proposed by Staiger and Stock 
(1997) for instrument as validation is an F-value of 10 or larger for a single endogenous regressor. As shown in panel $B$ in Table 3, the $F$ statistics are $>10$ in all specifications. The first-stage regressions also pass another simple rule of thumb, which is that the $R^{2}$, also known as the Shea partial $R^{2}$, should be larger than 0.3 (Shea, 1997). The $R^{2}$ in our first-stage regressions is around 0.7.

We apply a test for overidentifying restrictions to determine whether our instruments are uncorrelated with the error term in equation (1) (Sargan, 1958). Results of the Sargan overidentification test are also reported in Table $\underline{\mathbf{3}}$, including chi-square statistics and corresponding $p$-values. The null hypothesis in this case is that the error term is uncorrelated with the instruments. The overidentification test results in general show that our instruments are orthogonal to the error term in equation (1).

A final check is a determination that those instruments do not themselves belong in the equation. In other words, we should not observe a direct relationship between those instruments and change in migration. To implement this test, a second set of instruments is introduced for the purpose of identifying the equation. The second set of instruments includes a measure of host business climate published by Business Environment Risk Intelligence and a dummy variable indicating whether a bilateral investment treaty is in place between host and home of FDI. The IV regression implies that conditional on control variables included in the model, the only impact of the original set of instruments on migration should only come through a change in FDI. Results in panel $\mathrm{C}$ in Table $\mathbf{3}$ show that the coefficients on the original set of instruments are not significant in the migration regressions. It confirms that the original instruments do not have direct effects on migration, but only indirect influence on migration through FDI. Sargan overidentification test reported in panel C also shows that the second set of instruments is valid.

Going back to Table 2, the coefficients on the key independent variable, inward FDI, are negative and significant at the 1 per cent level in all 30 regressions. The baseline results show that FDI has a robust negative effect on migration regardless of the education level of the migrants. As mentioned previously, inward FDI in LDCs can reduce out-migration by providing better income prospects for prospective migrants and by improving macroeconomic conditions in the host country. We refer this result as the home effect of FDI, which indicates prospective migrants are more likely to stay in their home countries (Sauvant et al., 1993; Borjas,

1999; Sanderson and Kentor, 2008).

Sobel (2002, p. 139) describes social capital as 'circumstances in which individuals can use membership in groups and networks to secure benefits'. The importance of network effect or social capital has been recognised by a number of studies (Massey and Espinosa, 1997; Kanaiaupuni, 2000; Munshi, 2003). As pointed out by Massey and Espinosa (1997, p. 951), social capital theory envisions that ties to current or former migrants represent a valuable social asset since these connections can be used to acquire information and assistance that reduce the costs and risks of (international migration)'. Previous studies mostly use individual survey data to assess the impact of connections with relatives and friends who have migratory experience on the decision of prospective migrants. Given our data are aggregated at the country level, in Table 4, we include the migration from $j$ to $i$ as of 1990 as a measure of the size of existing migrants communities and thus a proxy for social network..$^{15}$ The empirical model with the initial migration is estimated as follows:

migration $_{j i}^{e}=\alpha+\beta F D I_{i j, 1990}+\gamma$ migration $_{j i, 1990}^{e}+\delta^{\prime} Z_{1990}+\varepsilon_{i j}{ }^{\cdot}$ (3)

Table 4. The Impact of Foreign Direct Investment (FDI) on Migration Controlling for Initial Migration Level 


\begin{tabular}{|c|c|c|c|c|c|c|c|c|c|c|}
\hline & SUR1 & SUR2 & SUR3 & SUR4 & SUR5 & 3SLS1 & 3SLS2 & 3SLS3 & 3SLS4 & 3SLS5 \\
\hline \multicolumn{11}{|l|}{$\begin{array}{l}\text { Panel A: } \\
\text { Tertiary } \\
\text { education } \\
\text { migration }\end{array}$} \\
\hline $\mathrm{FDI}_{1990}$ & $\begin{array}{l}-0.07 \\
272 * * \\
* \\
(0.023 \\
86)\end{array}$ & $\begin{array}{l}-0.09 \\
933^{* *} \\
* \\
(0.025 \\
18)\end{array}$ & $\begin{array}{l}-0.07218 \\
* * * \\
(0.02377)\end{array}$ & $\begin{array}{l}-0.07219 \\
* * * \\
(0.02380)\end{array}$ & $\begin{array}{l}-0.06742 \\
* * * \\
(0.02371)\end{array}$ & $\begin{array}{l}-0.2084 \\
1 * * * \\
(0.041)\end{array}$ & $\begin{array}{l}-0.24 \\
281^{* *} \\
* \\
(0.043 \\
)\end{array}$ & $\begin{array}{l}-0.207 \\
21^{* * *} \\
(0.041)\end{array}$ & $\begin{array}{l}-0.20 \\
747^{* *} \\
* \\
(0.041 \\
)\end{array}$ & $\begin{array}{l}-0.208 \\
57^{* * *} \\
(0.043 \\
)\end{array}$ \\
\hline $\begin{array}{l}\text { Tertiary } \\
\text { migration }_{199} \\
0\end{array}$ & $\begin{array}{l}-0.25 \\
333 * * \\
* \\
(0.026 \\
64)\end{array}$ & $\begin{array}{l}-0.22 \\
815^{* *} \\
* \\
(0.027 \\
58)\end{array}$ & $\begin{array}{l}-0.25389 \\
* * * \\
(0.02654)\end{array}$ & $\begin{array}{l}-0.25407 \\
* * * \\
(0.02658)\end{array}$ & $\begin{array}{l}-0.26158 \\
* * * \\
(0.02619)\end{array}$ & $\begin{array}{l}-0.1135 \\
2 * * \\
(0.045)\end{array}$ & $\begin{array}{l}-0.08 \\
234^{*} \\
(0.046 \\
)\end{array}$ & $\begin{array}{l}-0.114 \\
87^{* * *} \\
(0.044)\end{array}$ & $\begin{array}{l}-0.11 \\
442 * * \\
(0.044 \\
)\end{array}$ & $\begin{array}{l}-0.118 \\
57^{* * *} \\
(0.046 \\
)\end{array}$ \\
\hline$R^{2}$ & $\begin{array}{l}0.937 \\
2\end{array}$ & $\begin{array}{l}0.942 \\
7\end{array}$ & 0.9378 & 0.9379 & 0.9404 & 0.9145 & $\begin{array}{l}0.923 \\
1\end{array}$ & 0.9156 & $\begin{array}{l}0.915 \\
3\end{array}$ & 0.9164 \\
\hline \multicolumn{11}{|l|}{$\begin{array}{l}\text { Panel B: } \\
\text { Secondary } \\
\text { education } \\
\text { migration }\end{array}$} \\
\hline $\mathrm{FDI}_{1990}$ & $\begin{array}{l}-0.00 \\
603^{* *} \\
* \\
(0.001 \\
92)\end{array}$ & $\begin{array}{l}-0.00 \\
652 * * \\
* \\
(0.001 \\
95)\end{array}$ & $\begin{array}{l}-0.00561 \\
* * * \\
(0.00189)\end{array}$ & $\begin{array}{l}-0.00603 \\
* * * \\
(0.00185)\end{array}$ & $\begin{array}{l}-0.00606 \\
* * * \\
(0.00204)\end{array}$ & $\begin{array}{l}-0.0074 \\
2 * * * \\
(0.002)\end{array}$ & $\begin{array}{l}-0.00 \\
793^{* *} \\
* \\
(0.002 \\
)\end{array}$ & $\begin{array}{l}-0.006 \\
87 * * * \\
(0.002)\end{array}$ & $\begin{array}{l}-0.00 \\
730 * * \\
* \\
(0.002 \\
)\end{array}$ & $\begin{array}{l}-0.007 \\
66 * * * \\
(0.002 \\
)\end{array}$ \\
\hline $\begin{array}{l}\text { Secondary } \\
\text { migration }_{199} \\
0\end{array}$ & $\begin{array}{l}-0.10 \\
295^{* *} \\
* \\
(0.026 \\
77)\end{array}$ & $\begin{array}{l}-0.09 \\
725^{* *} \\
* \\
(0.026 \\
96)\end{array}$ & $\begin{array}{l}-0.10036 \\
* * * \\
(0.02569)\end{array}$ & $\begin{array}{l}-0.10465 \\
* * * \\
(0.02632)\end{array}$ & $\begin{array}{l}-0.10481 \\
* * * \\
(0.02925)\end{array}$ & $\begin{array}{l}-0.0776 \\
1 * * * \\
(0.027)\end{array}$ & $\begin{array}{l}-0.06 \\
987^{* *} \\
(0.027 \\
)\end{array}$ & $\begin{array}{l}-0.075 \\
28 * * * \\
(0.026)\end{array}$ & $\begin{array}{l}-0.08 \\
028^{* *} \\
* \\
(0.027 \\
)\end{array}$ & $\begin{array}{l}-0.074 \\
45^{* *} \\
(0.030 \\
)\end{array}$ \\
\hline$R^{2}$ & $\begin{array}{l}0.349 \\
8\end{array}$ & 0.367 & 0.3747 & 0.4008 & 0.3492 & 0.3667 & $\begin{array}{l}0.383 \\
6\end{array}$ & 0.3937 & $\begin{array}{l}0.417 \\
2\end{array}$ & 0.3719 \\
\hline \multicolumn{11}{|l|}{$\begin{array}{l}\text { Panel C: } \\
\text { Primary } \\
\text { education } \\
\text { migration }\end{array}$} \\
\hline $\mathrm{FDI}_{1990}$ & $\begin{array}{l}-0.00 \\
14 \\
(0.001 \\
22)\end{array}$ & $\begin{array}{l}-0.00 \\
195 \\
(0.001 \\
24)\end{array}$ & $\begin{array}{l}-0.00135 \\
(0.00117)\end{array}$ & $\begin{array}{l}-0.00163 \\
(0.00119)\end{array}$ & $\begin{array}{l}-0.00189 \\
(0.00121)\end{array}$ & $\begin{array}{l}-0.0012 \\
(0.001)\end{array}$ & $\begin{array}{l}-0.00 \\
156 \\
(0.001 \\
)\end{array}$ & $\begin{array}{l}-0.001 \\
32 \\
(0.001)\end{array}$ & $\begin{array}{l}-0.00 \\
136 \\
(0.001 \\
)\end{array}$ & $\begin{array}{l}-0.001 \\
86 \\
(0.001 \\
)\end{array}$ \\
\hline $\begin{array}{l}\text { Primary } \\
\text { migration }_{199} \\
0\end{array}$ & $\begin{array}{l}-0.16 \\
922 * * \\
* \\
(0.016 \\
98)\end{array}$ & $\begin{array}{l}-0.16 \\
333^{* *} \\
* \\
(0.017 \\
09)\end{array}$ & $\begin{array}{l}-0.16993 \\
* * * \\
(0.01600)\end{array}$ & $\begin{array}{l}-0.16510 \\
* * * \\
(0.01676)\end{array}$ & $\begin{array}{l}-0.17302 \\
* * * \\
(0.01642)\end{array}$ & $\begin{array}{l}-0.1720 \\
1 * * * \\
(0.018)\end{array}$ & $\begin{array}{l}-0.16 \\
824^{* *} \\
* \\
(0.018 \\
)\end{array}$ & $\begin{array}{l}-0.170 \\
92 * * * \\
(0.017)\end{array}$ & $\begin{array}{l}-0.16 \\
889 * * \\
* \\
(0.018 \\
)\end{array}$ & $\begin{array}{l}-0.173 \\
15^{* * *} \\
(0.018 \\
)\end{array}$ \\
\hline$R^{2}$ & $\begin{array}{l}0.787 \\
2\end{array}$ & 0.795 & 0.8038 & 0.8026 & 0.804 & 0.7864 & $\begin{array}{l}0.793 \\
2\end{array}$ & 0.8037 & $\begin{array}{l}0.801 \\
3\end{array}$ & 0.8044 \\
\hline
\end{tabular}




\begin{tabular}{|l|l|l|l|l|l|l|l|l|l|l|}
\hline $\begin{array}{l}\text { Observation } \\
\mathrm{S}\end{array}$ & 82 & 81 & 82 & 82 & 82 & 80 & 79 & 80 & 80 & 80 \\
\hline
\end{tabular}

Notes:

(i) Standard errors in brackets.

(ii) $* * *, * *, *$ Significant at $1 \%, 5 \%$ and $10 \%$, respectively. (iii) SUR1 includes control variables: common language, distance, political freedom, landlocked, income and unemployment; SUR2 includes the control variables in SURI and trade; SUR3 includes the control variables in SUR1 and inflation; SUR4 includes the control variables in SURI and common border; SUR5 includes the control variables in SUR1 and regional dummies (South Asia and West European countries). (iv) The set of instrumental variables for the three-stage least squares regressions (3SLS) is as follows: the log value of land area in host country, domestic credit provided by banking sector in host country as a share of GDP and double taxation treaty, which is a dummy variable indicating a double taxation treaty governing 'income and capital' in place between host and parent country.

Overall, the results from Table $\mathbf{4}$ indicate that, after controlling for the existing social network for prospective migrants, inward FDI tends to have a stronger home effect on the out-migration of individuals with tertiary education than on the out-migration of individuals with secondary education. With the addition of the social network proxy, panel A 3SLS shows the estimate of the coefficient on FDI in tertiary regressions is negative and significant, ranging from -0.24 to -0.20 . Similarly, the secondary regression results from panel $B$ show the coefficient on FDI is negative and statistically different from zero. The magnitude of the coefficient on FDI in the secondary regressions is between -0.0079 and -0.0069 . In absolute value, the FDI coefficient in the secondary regressions is significantly smaller than in the tertiary regressions. The coefficient on FDI in primary regressions in panel $C$ is negative, but is estimated imprecisely. Although inward FDI has a negative home effect in tertiary and secondary regressions, it does not seem to affect the out-migration of individuals with primary education. After we control for the effect of social capital, the deterrent effect of inward FDI on out-migration is much stronger for tertiary and secondary migration than for primary migration.

Taking a closer look at the effect of FDI on the migration of individuals with tertiary and secondary education, 3SLS1 in panel A suggests that a 1 per cent increase in inward FDI stock as a share of GDP from country $i$ to country $j$ tends to decrease the migration of individuals with tertiary education from $j$ to $i$ by 0.2 per cent, ceteris paribus. Given the sample mean of migration of individuals with tertiary education (relative to total population with tertiary education in the home country $j$ ) at 1.66 per cent in 2000, a 0.2 per cent change is equivalent to 12 per cent of the sample mean. Similarly, 3SLS1 in panel B indicates that a 1 per cent increase in inward FDI tends to decrease future migration of individuals with secondary education by 0.0074 per cent, holding other things constant. The sample average of migration of individuals with secondary education in 2000 is 0.294 per cent, and this change is equivalent to 2.5 per cent of the sample mean.

The deterrent effect of inward FDI on tertiary and secondary migration is consistent with the findings from previous studies on FDI (Howenstine and Zeile, 1994; Barba Navaretti and Venables, 2004), which indicate that foreign affiliates are more productive than domestic firms. If inward FDI transfers intangible assets and is correlated with an increase in demand for high-skilled labour (Feenstra and Hanson, 1996, 1997), individuals with tertiary or secondary education may be likely to be employed by affiliates of MNCs and take advantage of the higher wages and better job opportunities than individuals with only primary education. Therefore, inward FDI should have a stronger (negative) home effect on tertiary migration or secondary migration than primary migration. As the Development Gateway Foundation states in its website, 'the migration of skilled and educated 
individuals from one nation to another, is first and foremost a response to lack of opportunities at home. In recent years, countries like India and China, which have exported their brightest for decades, have started to reverse this trend. Outsourcing [FDI] is said to have played a large role by creating jobs, raising incomes and generating disciplined, efficient workforce that have in turn provided a platform for economic growth' ${ }^{16}$

Furthermore, we note that the migration from $j$ to $i$ as of 1990 is positively correlated with migration as of 2000 from $j$ to $i$, which is consistent with prior research on the relation between social capital and international migration.

According to equation (3), the actual effect of migration as of 1990 on migration as of 2000 would be $1+$ $\mathrm{\gamma} \cdot{ }^{17}$ The estimates from 3SLS1 in panel A in Table 4 indicate that initial tertiary migration is positively correlated with future tertiary migration with a magnitude of 0.88 . In other words, the more former migrants who leave from country of origin $j$ to destination country $i$, the easier will be future migration from $j$ to $i$ due to a stronger social network. ${ }^{18}$ The positive social network effect is robust across different specifications, regardless of the

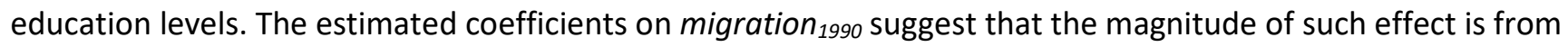
0.88 to 0.91 for tertiary regressions, 0.91 to 0.93 for secondary regressions and 0.74 to 0.83 for primary regressions.

According to these estimates, the positive social network effect is stronger for migration of individuals with secondary or primary education than for migration of individuals with tertiary education. It implies that the decisions of prospective migrants with relatively lower levels of education rely more on an existing community of migrants (with a similar education level) in the destination country than the decisions of prospective migrants with tertiary education. Another interesting result from these regressions is that social network seems to be a more important factor influencing the out-migration of individuals with primary education than FDI. Possible ties with former migrants in the destination country have a strong positive impact on the future primary education out-migration from the home country, but inward FDI in the home country may not necessarily have a significant impact.

\section{B. Separating Home And Linkage Effects Of Fdi}

Our previous results show that inward FDI can reduce out-migration from its host countries. However, some studies, such as, Sassen $(\mathbf{1 9 8 8}, \mathbf{1 9 9 3 )}$, also suggest that FDI can induce international migration as it creates cultural and ideological connections between the home country and the destination country (linkage effect).

As a result, the coefficient on the FDI variable in our previous regressions might not solely measure the home effect. Instead, it reflects the relative strength of linkage and home effects. To better distinguish between these two effects, ideally one would conduct a survey study asking prospective and existing migrants about their motivations of migration, which is beyond the scope of our current study. Alternatively, we attempt to

distinguish between home and linkage effects, albeit indirectly, by including a square term of FDI ( $F D I_{1990)}^{2}$ in our model:

$\operatorname{sigration}_{j i}^{e}=\alpha+\beta F D I_{i j, 1990}+\theta F D I_{i j, 1990}^{2}+\gamma$ migration $_{j i, 1990}^{e}+\delta^{\prime} Z_{1990}+\varepsilon_{i j \cdot}(4)$

The squared term allows us to capture any change in the effect of FDI on migration as the level of FDI changes. As a result, we can compare the relative strength of the home effect and the linkage effect. The results are shown in Table 5. 
Table 5. The Impacts of Foreign Direct Investment (FDI) and FDI Squared on Migration

\begin{tabular}{|c|c|c|c|c|c|c|c|c|c|c|}
\hline & SURI & SUR2 & SUR3 & SUR4 & SUR5 & 3SLS1 & 3SLS2 & 3SLS3 & 3SLS4 & 3SLS5 \\
\hline \multicolumn{11}{|l|}{$\begin{array}{l}\text { Panel A: } \\
\text { Tertiary } \\
\text { educatio } \\
\mathrm{n} \\
\text { migration }\end{array}$} \\
\hline $\mathrm{FDI}_{1990}$ & $\begin{array}{l}0.013 \\
34 \\
(0.040 \\
17)\end{array}$ & $\begin{array}{l}-0.04 \\
725 \\
(0.05 \\
953)\end{array}$ & $\begin{array}{l}0.02169 \\
(0.04019)\end{array}$ & $\begin{array}{l}0.01445 \\
(0.0399 \\
4)\end{array}$ & $\begin{array}{l}0.01811 \\
(0.0415 \\
0)\end{array}$ & $\begin{array}{l}-0.026 \\
17 \\
(0.080)\end{array}$ & $\begin{array}{l}-0.14 \\
7 \\
(0.145 \\
)\end{array}$ & $\begin{array}{l}0.00208 \\
(0.079)\end{array}$ & $\begin{array}{l}-0.02 \\
436 \\
(0.079 \\
)\end{array}$ & $\begin{array}{l}-0.01 \\
661 \\
(0.090 \\
)\end{array}$ \\
\hline $\begin{array}{l}\text { FDI }_{1990} \\
\text { squared }\end{array}$ & $\begin{array}{l}-0.17 \\
826^{* *} \\
(0.072 \\
17)\end{array}$ & $\begin{array}{l}-0.08 \\
598 \\
(0.09 \\
797)\end{array}$ & $\begin{array}{l}-0.19650 \\
* * * \\
(0.07257)\end{array}$ & $\begin{array}{l}-0.1795 \\
3^{* *} \\
(0.0717 \\
9)\end{array}$ & $\begin{array}{l}-0.1724 \\
9 * * \\
(0.0738 \\
7)\end{array}$ & $\begin{array}{l}-0.333 \\
84^{* *} \\
(0.132)\end{array}$ & $\begin{array}{l}-0.15 \\
068 \\
(0.226 \\
)\end{array}$ & $\begin{array}{l}-0.3908 \\
6 * * * \\
(0.132)\end{array}$ & $\begin{array}{l}-0.32 \\
955^{* *} \\
(0.130 \\
)\end{array}$ & $\begin{array}{l}-0.33 \\
582^{* *} \\
(0.146 \\
)\end{array}$ \\
\hline $\begin{array}{l}\text { Tertiary } \\
\text { migration } \\
1990\end{array}$ & $\begin{array}{l}-0.20 \\
832^{* *} \\
* \\
(0.033 \\
42)\end{array}$ & $\begin{array}{l}-0.21 \\
712^{* *} \\
* \\
(0.03 \\
362)\end{array}$ & $\begin{array}{l}-0.20297 \\
* * * \\
(0.03329)\end{array}$ & $\begin{array}{l}-0.2087 \\
0 * * * \\
(0.0333 \\
0)\end{array}$ & $\begin{array}{l}-0.2179 \\
6^{* * *} \\
(0.0335 \\
3)\end{array}$ & $\begin{array}{l}-0.050 \\
13 \\
(0.051)\end{array}$ & $\begin{array}{l}-0.06 \\
666 \\
(0.053 \\
)\end{array}$ & $\begin{array}{l}-0.0362 \\
3 \\
(0.051)\end{array}$ & $\begin{array}{l}-0.05 \\
542 \\
(0.050 \\
)\end{array}$ & $\begin{array}{l}-0.05 \\
843 \\
(0.051 \\
)\end{array}$ \\
\hline$R^{2}$ & $\begin{array}{l}0.941 \\
9\end{array}$ & $\begin{array}{l}0.943 \\
4\end{array}$ & 0.9432 & 0.9427 & 0.9445 & 0.9279 & $\begin{array}{l}0.928 \\
1\end{array}$ & 0.9291 & $\begin{array}{l}0.929 \\
7\end{array}$ & $\begin{array}{l}0.930 \\
7\end{array}$ \\
\hline \multicolumn{11}{|l|}{$\begin{array}{l}\text { Panel B: } \\
\text { Secondar } \\
\text { y } \\
\text { educatio } \\
\mathrm{n} \\
\text { migration }\end{array}$} \\
\hline $\mathrm{FDI}_{1990}$ & $\begin{array}{l}0.013 \\
20^{*} \\
(0.007 \\
48)\end{array}$ & $\begin{array}{l}0.022 \\
82^{* *} \\
(0.01 \\
108)\end{array}$ & $\begin{array}{l}0.01358 * \\
(0.00740)\end{array}$ & $\begin{array}{l}0.01377 \\
* \\
(0.0071 \\
5)\end{array}$ & $\begin{array}{l}0.01444 \\
* \\
(0.0078 \\
3)\end{array}$ & $\begin{array}{l}0.0185 \\
(0.013)\end{array}$ & $\begin{array}{l}0.031 \\
2 \\
(0.024 \\
)\end{array}$ & $\begin{array}{l}0.02094 \\
* \\
(0.013)\end{array}$ & $\begin{array}{l}0.020 \\
18^{*} \\
(0.012 \\
)\end{array}$ & $\begin{array}{l}0.023 \\
45 \\
(0.015 \\
)\end{array}$ \\
\hline $\begin{array}{l}\mathrm{FDI}_{1990} \\
\text { squared }\end{array}$ & $\begin{array}{l}-0.02 \\
884 * * \\
* \\
(0.010 \\
69)\end{array}$ & $\begin{array}{l}-0.04 \\
207 * * \\
* \\
(0.01 \\
555)\end{array}$ & $\begin{array}{l}-0.02872 \\
* * * \\
(0.01058)\end{array}$ & $\begin{array}{l}-0.0296 \\
9 * * * \\
(0.0102 \\
2)\end{array}$ & $\begin{array}{l}-0.0302 \\
5 * * * \\
(0.0109 \\
7)\end{array}$ & $\begin{array}{l}-0.036 \\
92 * * \\
(0.018)\end{array}$ & $\begin{array}{l}-0.05 \\
429 * \\
(0.034 \\
)\end{array}$ & $\begin{array}{l}-0.0396 \\
8 * * \\
(0.018)\end{array}$ & $\begin{array}{l}-0.03 \\
915^{* *} \\
(0.017 \\
)\end{array}$ & $\begin{array}{l}-0.04 \\
321 * * \\
(0.020 \\
)\end{array}$ \\
\hline $\begin{array}{l}\text { Secondar } \\
\text { y } \\
\text { migration } \\
1990\end{array}$ & $\begin{array}{l}-0.07 \\
869 * * \\
* \\
(0.026 \\
78)\end{array}$ & $\begin{array}{l}-0.07 \\
092 * * \\
* \\
(0.02 \\
688)\end{array}$ & $\begin{array}{l}-0.07648 \\
* * * \\
(0.02592)\end{array}$ & $\begin{array}{l}-0.0792 \\
5 * * * \\
(0.0262 \\
2)\end{array}$ & $\begin{array}{l}-0.0757 \\
9 * * * \\
(0.0289 \\
9)\end{array}$ & $\begin{array}{l}-0.060 \\
73 * * \\
(0.027)\end{array}$ & $\begin{array}{l}-0.05 \\
169^{*} \\
(0.029 \\
)\end{array}$ & $\begin{array}{l}-0.0558 \\
8 * * \\
(0.026)\end{array}$ & $\begin{array}{l}-0.06 \\
262^{* *} \\
(0.026 \\
)\end{array}$ & $\begin{array}{l}-0.05 \\
445^{*} \\
(0.029 \\
)\end{array}$ \\
\hline$R^{2}$ & $\begin{array}{l}0.410 \\
3\end{array}$ & $\begin{array}{l}0.427 \\
1\end{array}$ & 0.4343 & 0.4634 & 0.415 & 0.4323 & $\begin{array}{l}0.448 \\
4\end{array}$ & 0.4576 & $\begin{array}{l}0.485 \\
9\end{array}$ & $\begin{array}{l}0.438 \\
8\end{array}$ \\
\hline $\begin{array}{l}\text { Panel C: } \\
\text { Primary } \\
\text { educatio } \\
\text { n } \\
\text { migration }\end{array}$ & & & & & & & & & & \\
\hline
\end{tabular}




\begin{tabular}{|c|c|c|c|c|c|c|c|c|c|c|}
\hline $\mathrm{FDI}_{1990}$ & $\begin{array}{l}0.003 \\
85 \\
(0.003 \\
69)\end{array}$ & $\begin{array}{l}0.001 \\
33 \\
(0.00 \\
545)\end{array}$ & $\begin{array}{l}0.00534 \\
(0.00354)\end{array}$ & $\begin{array}{l}0.00407 \\
(0.0035 \\
4)\end{array}$ & $\begin{array}{l}0.00134 \\
(0.0037 \\
5)\end{array}$ & $\begin{array}{l}0.0082 \\
(0.007)\end{array}$ & $\begin{array}{l}0.010 \\
8 \\
(0.012 \\
)\end{array}$ & $\begin{array}{l}0.00808 \\
(0.006)\end{array}$ & $\begin{array}{l}0.008 \\
84 \\
(0.006 \\
)\end{array}$ & $\begin{array}{l}0.006 \\
08 \\
(0.007 \\
)\end{array}$ \\
\hline $\begin{array}{l}\mathrm{FDI}_{1990} \\
\text { squared }\end{array}$ & $\begin{array}{l}-0.00 \\
807 \\
(0.005 \\
33)\end{array}$ & $\begin{array}{l}-0.00 \\
456 \\
(0.00 \\
767)\end{array}$ & $\begin{array}{l}-0.01040 \\
* * \\
(0.00511)\end{array}$ & $\begin{array}{l}-0.0088 \\
8^{*} \\
(0.0051 \\
3)\end{array}$ & $\begin{array}{l}-0.0047 \\
3 \\
(0.0053 \\
2)\end{array}$ & $\begin{array}{l}-0.013 \\
48 \\
(0.009)\end{array}$ & $\begin{array}{l}-0.01 \\
704 \\
(0.016 \\
)\end{array}$ & $\begin{array}{l}-0.0136 \\
7 \\
(0.009)\end{array}$ & $\begin{array}{l}-0.01 \\
470 * \\
(0.009 \\
)\end{array}$ & $\begin{array}{l}-0.01 \\
094 \\
(0.010 \\
)\end{array}$ \\
\hline $\begin{array}{l}\text { Primary } \\
\text { migration } \\
1990\end{array}$ & $\begin{array}{l}-0.16 \\
289 * * \\
* \\
(0.017 \\
41)\end{array}$ & $\begin{array}{l}-0.16 \\
374^{* *} \\
* \\
(0.01 \\
739)\end{array}$ & $\begin{array}{l}-0.16038 \\
* * * \\
(0.01633)\end{array}$ & $\begin{array}{l}-0.1566 \\
7 * * * \\
(0.0171 \\
4)\end{array}$ & $\begin{array}{l}-0.1709 \\
7 * * * \\
(0.0169 \\
1)\end{array}$ & $\begin{array}{l}-0.167 \\
51 * * * \\
(0.018)\end{array}$ & $\begin{array}{l}-0.16 \\
658^{* *} \\
* \\
(0.018 \\
)\end{array}$ & $\begin{array}{l}-0.1642 \\
6 * * * \\
(0.017)\end{array}$ & $\begin{array}{l}-0.16 \\
301 * * \\
* \\
(0.018 \\
)\end{array}$ & $\begin{array}{l}-0.17 \\
156^{* *} \\
* \\
(0.018 \\
)\end{array}$ \\
\hline$R^{2}$ & 0.795 & $\begin{array}{l}0.795 \\
8\end{array}$ & 0.8158 & 0.8119 & 0.8067 & 0.7902 & $\begin{array}{l}0.787 \\
5\end{array}$ & 0.8143 & $\begin{array}{l}0.806 \\
2\end{array}$ & $\begin{array}{l}0.803 \\
5\end{array}$ \\
\hline $\begin{array}{l}\text { Observati } \\
\text { ons }\end{array}$ & 82 & 81 & 82 & 82 & 82 & 80 & 79 & 80 & 80 & 80 \\
\hline
\end{tabular}

Notes:

(i) Standard errors in brackets.

(ii) $* * *, * *, *$ Significant at $1 \%, 5 \%$ and $10 \%$, respectively. (iii) SUR1 includes control variables: common language, distance, political freedom, landlocked, income and unemployment; SUR2 includes the control variables in SURI and trade; SUR3 includes the control variables in SUR1 and inflation; SUR4 includes the control variables in SUR1 and common border; SUR5 includes the control variables in SURI and regional dummies (South Asia and West European countries). (iv) The set of instrumental variables for the three-stage least squares regressions (3SLS) is as follows: the log value of land area in host country, domestic credit provided by banking sector in host country as a share of GDP and double taxation treaty, which is a dummy variable indicating a double taxation treaty governing 'income and capital' in place between host and parent country.

We observe from the tertiary regressions in panel A that the coefficient on $F D I_{i j, 1990}^{2}$ is negative and significant. The stand-alone FDI is also in general negative, but not significant at conventional levels. It seems that for migration of individuals with tertiary education, we only observe a much stronger home effect of inward FDI (represented by a significantly negative coefficient on $F D I_{i j, 1990)}^{2}$. The linkage effect may not be discernible as it is expected to be represented by a positive coefficient on the stand-alone FDI. In other words, inward FDI is more likely to decrease the migration of individuals with tertiary education.

In panel B for the secondary migration regressions, the coefficient on FDI is positive and significant in the SUR regressions, but only significant in two out of five 3SLS regressions. The coefficient on the squared FDI is negative and significant. It appears that FDI can have a positive effect on migration (that is, the linkage effect exceeds the home effect). Conceptually, the net effect of FDI on migration is as follows: $\partial \Delta$ migration ${ }_{j i}^{e} / \partial F D I_{i j}=\beta+2 \theta F D I_{i j}$. Since $\beta$ is positive and the coefficient on squared FDI is negative (i.e. $\theta>0$ ), the net effect of FDI on migration ( $\partial \Delta$ mi gration ${ }_{j i}^{e} / \partial F D I_{i j}$ ) can be either positive or negative depending on the existing level of FDI in the host country.

Taken as a whole, the results in Table $\mathbf{5}$ show that: (i) inward FDI has a dominant home effecton individuals with tertiary education than on individuals with secondary education, and (ii) inward FDI seems to have a 
relatively stronger linkage effect on individuals with secondary education than on individuals with tertiary education. In contrast, most coefficients on both the stand-alone FDI and the squared FDI in primary regressions (panel C) are not statistically significant. This confirms that inward FDI affects out-migration of individuals with tertiary or secondary education, but does not generally have a significant effect on the out-migration of individuals with primary education. As mentioned previously, affiliates of MNCs, being more capital-intensive and more productive than national firms, tend to favour high-skilled labour to low-skilled labour. Individuals with primary education might not be able to obtain the higher-paying jobs and experience the 'western' culture embodied by the affiliates of MNCs. Thus, FDI does not have a significant influence (either home or linkage effect) on out-migration of individuals with primary education.

These findings again confirm the hypothesis of FDI as a potential source for skill-biased technological change (SBTC) suggested by prior research. In general, most LDCs are high-skilled labour scarce and low-skilled labour abundant. Although MNCs employ individuals with different levels of education, inward FDI tends to raise relative demand for high-skilled labour (Feenstra and Hanson, 1996, 1997) in LDCs. In turn, a rise in the level of inward FDI (or more affiliates of MNCs) in LDCs increases the wage for individuals with tertiary education much faster than individuals with secondary (or primary) education. Consequently, we observe a stronger home effect of FDI on tertiary migration than on secondary migration.

\section{Fdi From Other Countries}

One may suspect that the effects of FDI might not be limited to a specific country pair. For example, FDI from the US to Thailand can affect Thai migration to the US. But FDI in Thailand from other DCs might also affect migration from Thailand to the US. To examine this potential effect, we create a variable measuring FDI from other countries (OCFDI) and include it in the regression. The OCFDI is constructed as:

$O C F D I_{j, 1990}=\sum_{k \neq i} F D I_{k j, 1990}$,

where $k$, $i$ in $\{$ high-income $O E C D$ countries $\}$ and $F D I_{k j, 1990}$ is the inward FDI stock in country from country $k$ as a share of country j's GDP in 1990. The regression results with this new variable are reported in $\underline{\text { Table } 6}$.

Table 6. The Impacts of Foreign Direct Investment (FDI) and Other Countries' FDI on Migration

\begin{tabular}{|c|c|c|c|c|c|c|c|c|c|c|}
\hline & SURI & SUR2 & SUR3 & SUR4 & SUR5 & 3SLS1 & 3SLS2 & 3SLS3 & 3SLS4 & 3SLS5 \\
\hline $\begin{array}{l}\text { Panel A } \\
\text { Tertiary } \\
\text { educati } \\
\text { on } \\
\text { migratic } \\
n\end{array}$ & & & & & & & & & & \\
\hline $\mathrm{FDI}_{1990}$ & $\begin{array}{l}0.0442 \\
6 \\
(0.0420 \\
9)\end{array}$ & $\begin{array}{l}-0.019 \\
18 \\
(0.0591 \\
1)\end{array}$ & $\begin{array}{l}0.0550 \\
7 \\
(0.0422 \\
8)\end{array}$ & $\begin{array}{l}0.0444 \\
7 \\
(0.0419 \\
3)\end{array}$ & $\begin{array}{l}0.0422 \\
8 \\
(0.0440 \\
4)\end{array}$ & $\begin{array}{l}0.0733 \\
4 \\
(0.070)\end{array}$ & $\begin{array}{l}0.0095 \\
5 \\
(0.127)\end{array}$ & $\begin{array}{l}0.1054 \\
3 \\
(0.067)\end{array}$ & $\begin{array}{l}0.0711 \\
5 \\
(0.070)\end{array}$ & $\begin{array}{l}0.1117 \\
(0.072)\end{array}$ \\
\hline $\begin{array}{l}\mathrm{FDI}_{1990} \mathrm{~S} \\
\text { quared }\end{array}$ & $\begin{array}{l}-0.198 \\
75^{* * *} \\
(0.0709 \\
2)\end{array}$ & $\begin{array}{l}-0.101 \\
64 \\
(0.0952 \\
6)\end{array}$ & $\begin{array}{l}-0.218 \\
46 * * * \\
(0.0714 \\
7)\end{array}$ & $\begin{array}{l}-0.200 \\
32 * * * \\
(0.0707 \\
1)\end{array}$ & $\begin{array}{l}-0.192 \\
47^{* *} \\
(0.0741 \\
4)\end{array}$ & $\begin{array}{l}-0.419 \\
91 * * * \\
(0.117)\end{array}$ & $\begin{array}{l}-0.328 \\
52 \\
(0.199)\end{array}$ & $\begin{array}{l}-0.469 \\
36 * * * \\
(0.116)\end{array}$ & $\begin{array}{l}-0.417 \\
59 * * * \\
(0.117)\end{array}$ & $\begin{array}{l}-0.472 \\
96 * * * \\
(0.126)\end{array}$ \\
\hline
\end{tabular}




\begin{tabular}{|c|c|c|c|c|c|c|c|c|c|c|}
\hline $\begin{array}{l}\quad \text { Other } \\
\text { countrie } \\
\mathrm{s}^{\prime} \\
\mathrm{FDI}_{1990}\end{array}$ & $\begin{array}{l}-0.061 \\
77^{*} \\
(0.0348 \\
8)\end{array}$ & $\begin{array}{l}-0.064 \\
31^{*} \\
(0.0351 \\
3)\end{array}$ & $\begin{array}{l}-0.069 \\
09 * * \\
(0.0348 \\
0)\end{array}$ & $\begin{array}{l}-0.060 \\
67^{*} \\
(0.0347 \\
7)\end{array}$ & $\begin{array}{l}-0.052 \\
97 \\
(0.0356 \\
5)\end{array}$ & $\begin{array}{l}-0.015 \\
72 \\
(0.043)\end{array}$ & $\begin{array}{c}-0.004 \\
(0.043)\end{array}$ & $\begin{array}{l}-0.029 \\
43 \\
(0.042)\end{array}$ & $\begin{array}{l}-0.013 \\
16 \\
(0.043)\end{array}$ & $\begin{array}{l}-0.018 \\
79 \\
(0.044)\end{array}$ \\
\hline $\begin{array}{l}\text { Other } \\
\text { countrie } \\
\mathrm{s}^{\prime} \\
\mathrm{FDI}_{1990} \mathrm{~S} \\
\text { quared }\end{array}$ & $\begin{array}{l}0.0826 \\
7 \\
(0.0643 \\
0)\end{array}$ & $\begin{array}{l}0.0881 \\
9 \\
(0.0649 \\
9)\end{array}$ & $\begin{array}{l}0.0968 \\
6 \\
(0.0651 \\
1)\end{array}$ & $\begin{array}{l}0.0827 \\
(0.0640 \\
7)\end{array}$ & $\begin{array}{l}0.0795 \\
9 \\
(0.0640 \\
4)\end{array}$ & $\begin{array}{l}0.0071 \\
6 \\
(0.077)\end{array}$ & $\begin{array}{l}-0.013 \\
02 \\
(0.077)\end{array}$ & $\begin{array}{l}0.0382 \\
9 \\
(0.077)\end{array}$ & $\begin{array}{l}0.0051 \\
4 \\
(0.077)\end{array}$ & $\begin{array}{l}0.0210 \\
4 \\
(0.077)\end{array}$ \\
\hline $\begin{array}{l}\text { Tertiary } \\
\text { migratio } \\
\mathrm{n}_{1990}\end{array}$ & $\begin{array}{l}-0.225 \\
75^{* * *} \\
(0.0334 \\
0)\end{array}$ & $\begin{array}{l}-0.235 \\
27 * * * \\
(0.0337 \\
2)\end{array}$ & $\begin{array}{l}-0.223 \\
03 * * * \\
(0.0331 \\
7)\end{array}$ & $\begin{array}{l}-0.224 \\
87^{* * *} \\
(0.0333 \\
8)\end{array}$ & $\begin{array}{l}-0.228 \\
57 * * * \\
(0.0338 \\
6)\end{array}$ & $\begin{array}{l}-0.087 \\
94^{*} \\
(0.047)\end{array}$ & $\begin{array}{l}-0.092 \\
07^{*} \\
(0.049)\end{array}$ & $\begin{array}{l}-0.084 \\
56^{*} \\
(0.047)\end{array}$ & $\begin{array}{l}-0.087 \\
58 * \\
(0.047)\end{array}$ & $\begin{array}{l}-0.084 \\
77^{*} \\
(0.049)\end{array}$ \\
\hline $\mathrm{R}^{2}$ & 0.9453 & 0.9468 & 0.9468 & 0.9457 & 0.946 & 0.9373 & 0.9389 & 0.9388 & 0.9378 & 0.9367 \\
\hline \multicolumn{11}{|l|}{$\begin{array}{l}\text { Panel B: } \\
\text { Seconda } \\
\text { ry } \\
\text { educati } \\
\text { on } \\
\text { migratio } \\
\text { n }\end{array}$} \\
\hline $\mathrm{FDI}_{1990}$ & $\begin{array}{l}0.0144 \\
9 * \\
(0.0081 \\
0)\end{array}$ & $\begin{array}{l}0.0233 \\
5^{* *} \\
(0.0113 \\
2)\end{array}$ & $\begin{array}{l}0.0145 \\
7^{*} \\
(0.0080 \\
4)\end{array}$ & $\begin{array}{l}0.0145 \\
9 * \\
(0.0077 \\
4)\end{array}$ & $\begin{array}{l}0.0161 \\
7^{*} \\
(0.0084 \\
4)\end{array}$ & $\begin{array}{l}0.0206 \\
9 * \\
(0.012)\end{array}$ & $\begin{array}{l}0.0357 \\
6 * \\
(0.022)\end{array}$ & $\begin{array}{l}0.0163 \\
9 \\
(0.011)\end{array}$ & $\begin{array}{l}0.0200 \\
2 * \\
(0.012)\end{array}$ & $\begin{array}{l}0.0249 \\
1 * * \\
(0.012)\end{array}$ \\
\hline $\begin{array}{l}\mathrm{FDI}_{1990} \mathrm{~S} \\
\text { quared }\end{array}$ & $\begin{array}{l}-0.030 \\
02 * * * \\
(0.0113 \\
6)\end{array}$ & $\begin{array}{l}-0.042 \\
25^{* * *} \\
(0.0157 \\
9)\end{array}$ & $\begin{array}{l}-0.029 \\
64 * * * \\
(0.0113 \\
0)\end{array}$ & $\begin{array}{l}-0.030 \\
43 * * * \\
(0.0108 \\
5)\end{array}$ & $\begin{array}{l}-0.032 \\
26 * * * \\
(0.0116 \\
7)\end{array}$ & $\begin{array}{l}-0.039 \\
33 * * \\
(0.017)\end{array}$ & $\begin{array}{l}-0.060 \\
10 * * \\
(0.030)\end{array}$ & $\begin{array}{l}-0.033 \\
35 * * \\
(0.016)\end{array}$ & $\begin{array}{l}-0.038 \\
76 * * \\
(0.016)\end{array}$ & $\begin{array}{l}-0.044 \\
74 * * * \\
(0.017)\end{array}$ \\
\hline $\begin{array}{l}\text { Other } \\
\text { countrie } \\
\text { s' FDI }_{1990}\end{array}$ & $\begin{array}{l}-0.002 \\
91 \\
(0.0068 \\
3)\end{array}$ & $\begin{array}{l}-0.002 \\
82 \\
(0.0068 \\
6)\end{array}$ & $\begin{array}{l}-0.002 \\
59 \\
(0.0067 \\
5)\end{array}$ & $\begin{array}{l}-0.002 \\
13 \\
(0.0065 \\
4)\end{array}$ & $\begin{array}{l}-0.003 \\
85 \\
(0.0069 \\
0)\end{array}$ & $\begin{array}{l}-0.000 \\
27 \\
(0.008)\end{array}$ & $\begin{array}{l}0.0006 \\
(0.007)\end{array}$ & $\begin{array}{l}0.0020 \\
8 \\
(0.007)\end{array}$ & $\begin{array}{l}0.0013 \\
3 \\
(0.007)\end{array}$ & $\begin{array}{l}-0.002 \\
38 \\
(0.008)\end{array}$ \\
\hline $\begin{array}{l}\text { Other } \\
\text { countrie } \\
\mathrm{s}^{\prime} \\
\mathrm{FDI}_{1990 \mathrm{~S}} \\
\text { quared }\end{array}$ & $\begin{array}{l}0.0039 \\
2 \\
(0.0123 \\
9)\end{array}$ & $\begin{array}{l}0.0039 \\
2 \\
(0.0124 \\
8)\end{array}$ & $\begin{array}{l}0.0061 \\
2 \\
(0.0123 \\
7)\end{array}$ & $\begin{array}{l}0.0038 \\
7 \\
(0.0118 \\
5)\end{array}$ & $\begin{array}{l}0.0043 \\
1 \\
(0.0123 \\
3)\end{array}$ & $\begin{array}{l}0.0004 \\
1 \\
(0.014)\end{array}$ & $\begin{array}{l}-0.001 \\
08 \\
(0.013)\end{array}$ & $\begin{array}{l}0.0001 \\
7 \\
(0.013)\end{array}$ & $\begin{array}{l}-0.000 \\
81 \\
(0.013)\end{array}$ & $\begin{array}{l}0.0023 \\
6 \\
(0.013)\end{array}$ \\
\hline $\begin{array}{l}\text { Seconda } \\
\text { ry } \\
\text { migratio } \\
\mathrm{n}_{1990}\end{array}$ & $\begin{array}{l}-0.091 \\
23 * * * \\
(0.0290 \\
0)\end{array}$ & $\begin{array}{l}-0.083 \\
33 * * * \\
(0.0292 \\
1)\end{array}$ & $\begin{array}{l}-0.086 \\
88 * * * \\
(0.0287 \\
0)\end{array}$ & $\begin{array}{l}-0.088 \\
19 * * * \\
(0.0284 \\
1)\end{array}$ & $\begin{array}{l}-0.083 \\
12 * * * \\
(0.0299 \\
0)\end{array}$ & $\begin{array}{l}-0.072 \\
06 * * \\
(0.030)\end{array}$ & $\begin{array}{l}-0.058 \\
42 * \\
(0.030)\end{array}$ & $\begin{array}{l}-0.061 \\
62 * * \\
(0.029)\end{array}$ & $\begin{array}{l}-0.068 \\
17^{* *} \\
(0.029)\end{array}$ & $\begin{array}{l}-0.063 \\
45^{* *} \\
(0.030)\end{array}$ \\
\hline $\mathrm{R}^{2}$ & 0.4071 & 0.4236 & 0.4317 & 0.4611 & 0.4161 & 0.4281 & 0.443 & 0.4677 & 0.4873 & 0.4358 \\
\hline $\begin{array}{l}\text { Panel C: } \\
\text { Primary } \\
\text { educati } \\
\text { on } \\
\text { migratio } \\
\text { n }\end{array}$ & & & & & & & & & & \\
\hline
\end{tabular}




\begin{tabular}{|c|c|c|c|c|c|c|c|c|c|c|}
\hline $\mathrm{FDI}_{1990}$ & $\begin{array}{l}0.0014 \\
8 \\
(0.0039 \\
1)\end{array}$ & $\begin{array}{l}-0.001 \\
11 \\
(0.0055 \\
0)\end{array}$ & $\begin{array}{l}0.0038 \\
8 \\
(0.0037 \\
6)\end{array}$ & $\begin{array}{l}0.0014 \\
4 \\
(0.0037 \\
1)\end{array}$ & $\begin{array}{l}-0.000 \\
69 \\
(0.0040 \\
1)\end{array}$ & $\begin{array}{l}0.0040 \\
3 \\
(0.006)\end{array}$ & $\begin{array}{l}0.0009 \\
6 \\
(0.011)\end{array}$ & $\begin{array}{l}0.0029 \\
(0.005)\end{array}$ & $\begin{array}{l}0.0034 \\
3 \\
(0.006)\end{array}$ & $\begin{array}{l}0.0072 \\
1 \\
(0.006)\end{array}$ \\
\hline $\begin{array}{l}\mathrm{FDI}_{1990 \mathrm{~S}} \\
\text { quared }\end{array}$ & $\begin{array}{l}-0.004 \\
66 \\
(0.0055 \\
4)\end{array}$ & $\begin{array}{l}-0.001 \\
04 \\
(0.0076 \\
9)\end{array}$ & $\begin{array}{l}-0.007 \\
75 \\
(0.0053 \\
1)\end{array}$ & $\begin{array}{l}-0.005 \\
19 \\
(0.0052 \\
6)\end{array}$ & $\begin{array}{l}-0.002 \\
17 \\
(0.0055 \\
7)\end{array}$ & $\begin{array}{l}-0.008 \\
19 \\
(0.008)\end{array}$ & $\begin{array}{l}-0.004 \\
01 \\
(0.015)\end{array}$ & $\begin{array}{l}-0.006 \\
89 \\
(0.008)\end{array}$ & $\begin{array}{l}-0.007 \\
98 \\
(0.008)\end{array}$ & $\begin{array}{l}-0.012 \\
35 \\
(0.008)\end{array}$ \\
\hline $\begin{array}{l}\quad \text { Other } \\
\text { countrie } \\
\mathrm{s}^{\prime} \\
\mathrm{FDI}_{1990}\end{array}$ & $\begin{array}{l}0.0043 \\
8 \\
(0.0031 \\
6)\end{array}$ & $\begin{array}{l}0.0041 \\
5 \\
(0.0032 \\
1)\end{array}$ & $\begin{array}{l}0.0026 \\
2 \\
(0.0030 \\
3)\end{array}$ & $\begin{array}{l}0.0048 \\
5 \\
(0.0030 \\
1)\end{array}$ & $\begin{array}{l}0.0041 \\
2 \\
(0.0032 \\
2)\end{array}$ & $\begin{array}{l}0.0044 \\
4 \\
(0.004)\end{array}$ & $\begin{array}{l}0.0047 \\
2 \\
(0.004)\end{array}$ & $\begin{array}{l}0.0042 \\
(0.003)\end{array}$ & $\begin{array}{l}0.0053 \\
1 \\
(0.003)\end{array}$ & $\begin{array}{l}0.0024 \\
5 \\
(0.004)\end{array}$ \\
\hline $\begin{array}{l}\text { Other } \\
\text { countrie } \\
\text { s' }^{\prime} \\
\mathrm{FDI}_{1990 \mathrm{~S}} \\
\text { quared }\end{array}$ & $\begin{array}{l}-0.005 \\
37 \\
(0.0058 \\
8)\end{array}$ & $\begin{array}{l}-0.004 \\
86 \\
(0.0059 \\
9)\end{array}$ & $\begin{array}{l}-0.000 \\
57 \\
(0.0057 \\
6)\end{array}$ & $\begin{array}{l}-0.005 \\
66 \\
(0.0055 \\
9)\end{array}$ & $\begin{array}{l}-0.005 \\
96 \\
(0.0057 \\
9)\end{array}$ & $\begin{array}{l}-0.005 \\
31 \\
(0.007)\end{array}$ & $\begin{array}{l}-0.005 \\
73 \\
(0.007)\end{array}$ & $\begin{array}{l}-0.002 \\
99 \\
(0.006)\end{array}$ & $\begin{array}{l}-0.006 \\
19 \\
(0.006)\end{array}$ & $\begin{array}{l}-0.002 \\
88 \\
(0.006)\end{array}$ \\
\hline $\begin{array}{l}\text { Primary } \\
\text { migratio } \\
\mathrm{n}_{1990}\end{array}$ & $\begin{array}{l}-0.166 \\
17^{* * *} \\
(0.0173 \\
2)\end{array}$ & $\begin{array}{l}-0.167 \\
39 * * * \\
(0.0173 \\
2)\end{array}$ & $\begin{array}{l}-0.168 \\
74 * * * \\
(0.0164 \\
8)\end{array}$ & $\begin{array}{l}-0.159 \\
10^{* * *} \\
(0.0168 \\
8)\end{array}$ & $\begin{array}{l}-0.168 \\
79 * * * \\
(0.0168 \\
9)\end{array}$ & $\begin{array}{l}-0.165 \\
42 * * * \\
(0.018)\end{array}$ & $\begin{array}{l}-0.165 \\
27 * * * \\
(0.018)\end{array}$ & $\begin{array}{l}-0.163 \\
38 * * * \\
(0.017)\end{array}$ & $\begin{array}{l}-0.158 \\
39 * * * \\
(0.018)\end{array}$ & $\begin{array}{l}-0.173 \\
15^{* * *} \\
(0.018)\end{array}$ \\
\hline $\mathrm{R}^{2}$ & 0.8031 & 0.8037 & 0.8258 & 0.8237 & 0.8118 & 0.8042 & 0.8059 & 0.8312 & 0.8262 & 0.8032 \\
\hline $\begin{array}{l}\text { Observa } \\
\text { tions }\end{array}$ & 82 & 81 & 82 & 82 & 82 & 80 & 79 & 80 & 80 & 80 \\
\hline
\end{tabular}

\section{Notes:}

(i) Standard errors in brackets.

(ii) $* * *, * *, *$ significant at $1 \%, 5 \%$ and $10 \%$, respectively. (iii) SURI includes control variables: common language, distance, political freedom, landlocked, income and unemployment; SUR2 includes the control variables in SURI and trade; SUR3 includes the control variables in SURI and inflation; SUR4 includes the control variables in SURI and common border; SUR5 includes the control variables in SURI and regional dummies (South Asia and West European countries). (iv) The set of instrumental variables for the three-stage least squares regressions (3SLS) is as follows: the log value of land area in host country, domestic credit provided by banking sector in host country as a share of GDP and double taxation treaty, which is a dummy variable indicating a double taxation treaty governing 'income and capital' in place between host and parent country.

The results from Table $\mathbf{6}$ are consistent with results from Table $\mathbf{5}$ in terms of the coefficients on FDI $_{1990}$ and

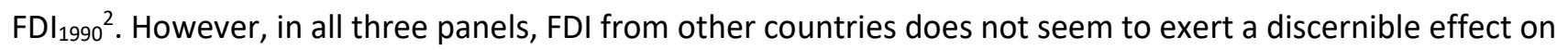
out-migration, regardless of migrants' level of education.

\section{Conclusion}

Our study is among the first ones to separately look at the impact of FDI in LDCs on the out-migration of individuals with three different levels of education. With data on migration from 19 LDCs to 14 DCs, we find that inward FDI in LDC tends to, in general, reduce out-migration of individuals with secondary and tertiary education, but has no significant impact on the out-migration of individuals with only primary education. 
Furthermore, our work goes beyond the examination of the net effect of FDI on the migration of individuals with tertiary and secondary education. It does this by focusing on the strength of the home effect and the linkage effect of FDI. We find that inward FDI in LDCs has a stronger home effect on tertiary education migration, while it has a stronger linkage effect on secondary and primary education migration.

FDI from other countries is a measure we use to capture the effect of FDI from countries other than the country of destination of interest. We find that in general FDI from other countries may not have a significant effect on migration of individuals compared to FDI from the destination country of interest.

International migration is an important component of globalisation and has emerged as a crucial issue facing both developed and less developed countries. Our results have important implications to policymakers, especially policymakers in LDCs. A better understanding of flows of migrants with different skills is key to enhance the role of migration in the development process. For example, to address the concern of brain drain, government policies might be effective in limiting skilled labour outflows temporarily. But the creation of economic incentives through the operation of market forces, such as inward FDI, would be the more effective way to retain skilled workers in their home countries. In addition, policies that help the government to keep a close tie with diaspora and encourage the return of them would also be beneficial to migrants-sending countries. Indirectly, our results also provide some support for preferential policies towards MNCs to attract more FDI.

\section{Footnotes}

1 According to the US Department of Commerce, inward FDI is defined as the direct or indirect ownership of at least 10 per cent of the voting power of a business enterprise by a single foreign parent corporation.

2 Interested readers are referred to Bellak (2004) for a detailed survey of studies on the performance gap between foreign affiliates and domestic firms.

3 In our study, 'home country' refers to the home country for migrants or the migrants-sending country; 'destination country' refers to the migrants-receiving country.

4 See http://nis.princeton.edu/.

5 Given an annual rate of economic growth of $x$ per cent, a country's average income will double in $(70 / x)$ years. To quadruple income from $\$ 975$ to $\$ 3,856$, it will take a country $2 \times(70 / 5)=28$ years with a 5 per cent economic growth rate, but only $2 \times(70 / 10)=14$ years for a country with 10 per cent economic growth rate.

6 See, for example, Bornschier and Chase-Dunn (1985), Sauvant et al. (1993), Blomstrom et al. (1994), Borensztein et al. (1998), Choe (2003), Alfaro et al. (2004), Blonigen and Wang (2005), Carkovic and Levine (2005) and Wang and Wong (2009) for discussions of the impact of FDI on economic growth in host countries.

7 We recognise that there can be two-way causality in a model involving inward FDI and out-migration. For example, the migration flow from country $A$ to country $B$ can also affect FDI from $B$ to $A$. To address the potential endogeneity problem, we introduce equation (1), where our independent variables are obtained from 1990 and the dependent variable, migration, is the change in migrants stock from 1990 to 2000. Intuitively, we argue that the change in migration after 1990 should not affect the initial level of FDI in 1990. As a result, this specification should prevent the reverse causality from FDI to migration.

8 The classification of high-income OECD countries is obtained from the World Bank.

9 Primary education is equivalent to zero to eight years of schooling, secondary education to 9-12 years of schooling and tertiary education to $13+$ years of schooling. According to Docquier and Marfouk (2004), the original information from different national population surveys and registered data includes only skill levels of migrants such as low-skilled, medium-skilled, high-skilled and unknown. They convert the skill levels into corresponding education levels. In addition, since Docquier and Marfouk use census and 
register data, illegal immigration is not captured. The measure also excludes a large number of students who are in foreign countries to complete their education.

10 Suppose that as of 1990, 1,000 people who have achieved secondary education are living in Canada (country i), but were born in Thailand (country j). Also suppose that in 1990, there are 100,000 people who were born and living in Thailand with secondary education. Then, the migration (rate) of individuals with secondary education from Thailand to Canada is mi gration $_{j i, t}^{e}=1,000 / 100,000=0.01$ or 1 per cent, where $e=$ secondary education, and $t=1990$.

11 We obtain data for Taiwan from the Asian Development Bank.

12 Common language consists of the official language as well as a language spoken by at least 9 per cent of the population.

13 Javorcik et al. (2011), with a panel model, adopt the instrumental variable approach to control for the endogeneity between FDI and migration in the same period $t$.

14 Due to the fact that we also have squared FDI in our models, powers of instruments are also included as instruments (Kelejian, 1971).

15 We report only the coefficients on FDI and initial migration. Other coefficient results are available upon request.

16 http://topics.developmentgateway.org/special/foreigninvestment/template31.do\#5.

17 Equation (3) is equivalent

$$
\text { to } \text { migration }_{j i, 2000}^{e}=\alpha+\beta F D I_{i j, 1990}+(1+\gamma) \text { migration }_{j i, 1990}^{e}+\delta^{\prime} Z_{1990}+\varepsilon_{i j} \text {. }
$$

18 We consider the following example: if there is already a well-established population from Thailand $(j)$ in the US (i), then new migrants from Thailand might find themselves relatively easily connected with the local community in terms of language, culture and job opportunities. As a result, migrants from Thailand are more likely to stay in the US, obtain a good job and further migration from Thailand to the US will be encouraged.

We are grateful to the associate editor, Richard Kneller, and the anonymous referee for providing invaluable comments to improve our paper. We also thank Bruce Blonigen, Brian Brush, David Clark, and Joseph Daniels for their helpful comments and insights. This research is supported by the Miles Research Grant from the College of Business Administration, Marquette University.

\section{APPENDIX}

\section{APPENDIX A}

Table A1. Destination and Home Countries

\begin{tabular}{|l|l|l|l|l|}
\hline Destination countries & & & \\
\hline Australia & France & Japan & New Zealand & Switzerland \\
\hline Austria & Germany & Korea & Norway & United Kingdom \\
\hline Canada & Italy & Netherlands & Sweden & United States \\
\hline Home countries & China & Hong Kong & Morocco & Senegal \\
\hline Argentina & Colombia & Hungary & Nigeria & Singapore \\
\hline Bahamas & Côte d'lvoire & India & Panama & South Africa \\
\hline Barbados & Czech Republic & Indonesia & Philippines & Taiwan \\
\hline Brazil & Egypt & Israel & Poland & Thailand \\
\hline Bulgaria & El Salvador & Malaysia & Romania & Turkey \\
\hline Cameroon & Gabon & Mexico & Saudi Arabia & Venezuela \\
\hline Chile & &
\end{tabular}




\section{References}

Alfaro, L., A. Chanda, S. Kalemli-Ozcan and S. Sayek (2004), 'FDI and Economic Growth: The Role of Local Financial Markets', Journal of International Economics, 64, 1, 89-112.

Aroca, P. and W. F. Maloney (2005), 'Migration, Trade and Foreign Direct Investment in Mexico', World Bank Economic Review, 19, 3, 449-72.

Barba Navaretti, G. and A. Venables (2004), Multinational Firms in the World Economy (Princeton, NJ: Princeton University Press).

Beine, M., F. Docquier and H. Rapoport (2008), 'Brain Drain and Human Capital Formation in Developing Countries: Winners and Losers', Economic Journal, 118, 528, 631-52.

Bellak, C. (2004), 'How Domestic and Foreign Firms Differ and Why Does it Matter?', Journal of Economic Surveys, 18, 4, 483-514.

Blomstrom, M., R. Lipsey and M. Zejan (1994), 'What Explains Growth in Developing Countries?', in W. Baumol, R. Nelson and E. Wolff (eds.), Convergence of Productivity: Cross-National Studies and Historical Evidence (Oxford: Oxford University Press), 243-59.

Blonigen, B. and M. Wang (2005), 'Inappropriate Pooling of Wealthy and Poor Countries in Empirical FDI Studies', in T. Moran, E. Graham and M. Blomstrom (eds.), Does Foreign Direct Investment Promote Development? (Washington, DC: Institute for International Economics Publication), 221-44.

Borensztein, E., J. De Gregorio and J.-W. Lee (1998), 'How does Foreign Direct Investment affect Economic Growth?', Journal of International Economics, 45, 1, 115-35.

Borjas, G. J. (1999), 'Economic Research on the Determinants of Immigration: Lessons for the European Union', Technical Paper \#438 (Washington DC: World Bank).

Bornschier, V. and C. Chase-Dunn (1985), Transnational Corporations and Underdevelopment (New York: Praeger).

Bureau of Economic Analysis (1989), US Direct Investment Abroad: 1989 Benchmark Survey(Washington, DC: US Department of Commerce).

Bureau of Economic Analysis (2004), US Direct Investment Abroad: 2004 Benchmark Survey(Washington, DC: US Department of Commerce).

Carkovic, Maria. and Ross. Levine (2005), 'Does Foreign Direct Investment Accelerate Economic Growth?', in T. Moran, E. Graham and M. Blomstrom (eds.), Does Foreign Direct Investment Promote Development? (Washington, DC: Institute for International Economics Publication), 195-220.

Carrington, W. J. and E. Detragiache (1998), 'How big is the Brain Drain?', Working Paper No 98 (Washington, DC: International Monetary Fund).

Choe, J. I. (2003), 'Do Foreign Direct Investment and Gross Domestic Investment Promote Economic Growth?', Review of Development Economics, 7, 1, 44-57.

Department of Homeland Security (1995), Yearbook of Immigration Statistics: 1995 (Washington, DC: Department of Homeland Security).

di Giovanni, J. (2005), 'What Drives Capital Flows? The Case of Cross-Border M\&A Activity and Financial Deepening', Journal of International Economics, 65, 1, 127-49.

Docquier, F. and E. Lodigiani (2010), 'Skilled Migration and Business Networks', Open Economic Review, 21, 4, 565-88.

Docquier, F. and A. Marfouk (2004), 'Measuring the International Mobility of Skilled Workers (1990-2000): Release 1.0', Policy, Research Working Paper Series No 3381 (Washington, DC: World Bank). 
Driffield, N. and K. Taylor (2002), 'Spillovers from FDI and Skill Structures of Host-Country Firms', Discussion Papers in Economics (Leicester: Department of Economics, University of Leicester).

Federal Reserve Bank of Dallas (2010), 'Spotlight: Maquiladora Employment New Data Confirm Pickup in Juárez Factory Jobs', South-West Economy, 2nd Quarter.

Feenstra, R. C. and G. H. Hanson (1996), 'Foreign Investment, Outsourcing and Relative Wages', in R. C. Feenstra, G. M. Grossman and D. A. Irwin (eds.), Political Economy of Trade Policy: Essays in Honor of Jagdish Bhagwati (Cambridge, MA: MIT Press), 89-128.

Feenstra, R. C. and G. H. Hanson (1997), 'Foreign Direct Investment and Relative Wages: Evidence from Mexico's Maquiladoras', Journal of International Economics, 42, 3, 371-93.

Figini, P. and H. Görg (1999), 'Multinational Companies and Wage Inequality in the Host Country: The Case of Ireland', Review of World Economics, 135, 4, 594-612.

Friedman, T. L. (2005), The World is Flat: A Brief History of the Twenty-First Century (New York: Farrar, Straus and Giroux Press).

Gao, T. (2003), 'Ethnic Chinese Networks and International Investment: Evidence from Inward FDI in China', Journal of Asian Economics, 14, 4, 611-29.

Greenwood, M. J. (1997), 'Internal Migration in Developed Countries', in M. R. Rosenzweig and O. Stark (eds.), Handbook of Families and Population Economics (Amsterdam: North-Holland), 647-720.

Greenwood, M. J. and J. M. McDowell (1991), 'Differential Economic Opportunity, Transferability of Skills, and Immigration to the United States and Canada', Review of Economics and Statistics, 73, 4, 612-23.

Hayase, Y. (2001), 'Japanese Foreign Direct Investment, Employment, and International Migration in East Asia', Asian and Pacific Migration Journal, 10, 3-4, 535-58.

Howenstine, N. G. and W. J. Zeile (1994), 'Characteristics of Foreign-Owned US Manufacturing Establishments', Survey of Current Business, 74, 1, 34-59.

Jasso, G. and M. R. Rosenzweig (2006), 'Characteristics of Immigrants to the United States: 1820-2003', in R. Ueda (ed.), Companion to American Immigration (Malden, MA: Blackwell Publishing), 328-58.

Javorcik, B., C. Özden, M. Spatareanu and C. Neagu (2011), 'Migrant Networks and Foreign Direct Investment', Journal of Development Economics, 94, 2, 231-41.

Kanaiaupuni, S. (2000), 'Reframing the Migration Question: An Analysis of Men, Women, and Gender in Mexico', Social Forces, 78, 4, 1311-48.

Kelejian, H. H. (1971), 'Two-Stage Least Squares and Econometric Systems in Parameters but Non-linear in the Endogenous Variables', Journal of the American Statistical Association, 66, 334, 373-374.

Kugler, M. and H. Rapoport (2007), 'International Labor and Capital Flows: Complements or Substitutes?', Economics Letters, 94, 2, 155-62.

Maddison, A. (2003), The World Economy: Historical Statistics (Paris: Organisation for Economic Co-operation and Development, Development Centre).

Massey, D. S. and K. E. Espinosa (1997), 'What's Driving Mexico-US Migration? A Theoretical, Empirical, and Policy Analysis', American Journal of Sociology, 102, 4, 939-99.

Munshi, K. (2003), 'Networks in the Modern Economy: Mexican Migrants in the US Labour Market', Quarterly Journal of Economics, 118, 2, 549-97.

Obstfeld, M. and K. Rogoff (1996), Foundations of International Macroeconomics (Cambridge, MA: MIT Press).

Rajan, R. and A. Subramanian (2008), 'Aid and Growth: What Does the Cross-Country Evidence Really Show?', The Review of Economics and Statistics, 90, 4, 643-65.

Romer, P. (1994), 'The Origins of Endogenous Growth', Journal of Economic Perspectives, 8, 1, 3-22. 
Sanderson, M. and J. Kentor (2008), 'Foreign Direct Investment and International Migration: A Cross-National Analysis of Less-Developed Countries, 1985-2000', International Sociology, 23, 4, 514-39.

Sargan, J. D. (1958), 'The Estimation of Economic Relationships Using Instrumental Variables', Econometrica, 26, 3, 393-415.

Sassen, S. (1988), The Mobility of Labor and Capital. A Study in International Investment and Labor Flow (Cambridge, MA: Cambridge University Press).

Sassen, S. (1993), Economic Internationalisation: The New Migration in Japan and the United States', International Migration, 31, 1, 73-102.

Sauvant, K. P., P. Mallampally and P. Economou (1993), 'Foreign Direct Investment and International Migration', Transnational Corporations, 2, 1, 33-69.

Shea, J. (1997), 'Instrument Relevance in Multivariate Linear Models: A Simple Measure', Review of Economics and Statistics, 79, 2, 348-52.

Sobel, J. (2002), 'Can We Trust Social Capital?', Journal of Economic Literature, XL, 13, 1, 9-54.

Solow, R. M. (1957), 'Technical Change and the Aggregate Production Function', Review of Economics and Statistics, 39, 3, 312-20.

Staiger, D. and J. H. Stock (1997), 'Instrumental Variables Regressions with Weak Instruments', Econometrica, 65, 3, 557-86.

Stein, E. and C. Daude (2007), 'Longitude Matters: Time Zones and the Location of Foreign Direct Investment', Journal of International Economics, 71, 1, 96-122.

Tong, S. Y. (2005), 'Ethnic Networks in FDI and the Impact of Institutional Development', Review of Development Economics, 9, 563-80.

United Nations (1992), World Investment Report 1992 (New York: UNCTAD).

United Nations (2006), World Investment Report 2006 (New York: UNCTAD).

United Nations (2010), World Investment Report 2010 (New York: UNCTAD).

United Nations (2011), World Investment Report 2011 (New York: UNCTAD).

Wang, M. and M. C. S. Wong (2009), 'FDI and Economic Growth: The Growth Accounting Perspective', Economic Inquiry, 47, 4, 701-10.

Wong, K. Y. and C. K. Yip (1999), 'Education, Economic Growth, and Brain Drain', Journal of Economic Dynamics and Control, 23, 5-6, 699-726. 